\title{
Influence of fault reactivation during multiphase rifting: the Oseberg area, Northern North Sea rift
}

Chao Deng ${ }^{1}$, Haakon Fossen ${ }^{2,1}$, Robert L. Gawthorpe ${ }^{1}$, Atle Rotevatn ${ }^{1}$, Christopher A-L. Jackson ${ }^{3}$, Hamed FazliKhani ${ }^{1}$

${ }^{1}$ Department of Earth Science, University of Bergen, Allégaten 41, 5007 Bergen, Norway

${ }^{2}$ Museum of Natural History, University of Bergen, Allégaten 41, 5007 Bergen, Norway

${ }^{3}$ Basins Research Group (BRG), Department of Earth Science \& Engineering, Imperial College, Prince Consort Road, London, SW7 2BP, UK

* Corresponding author: Department of Earth Science, University of Bergen, Allégaten 41, 5007 Bergen, Norway.

Tel: +861521087 7145

E-mail address: Chao.Deng@geo.uib.no, dengchao0926@gmail.com

Keywords: Multiphase rifting, Inter-rift fault activity, Structural inheritance, Fault interaction 


\section{Abstract}

Multiphase rifts tend to produce fault populations that evolve by the formation of new faults and reactivation of earlier faults. The resulting fault patterns tend to be complex and difficult to decipher. In this work we use seismic reflection data to examine the evolution of a normal fault network in the Oseberg Fault Block in the northern North Sea Rift System - a rift system that experienced Permian - Early Triassic and Middle Jurassic - Early Cretaceous rifting and exhibits N-S, NW-SE and NE-SW oriented faults.

Both N-S- and NW-SE-striking faults were established during the Permian - Early Triassic rifting, as indicated by Triassic growth packages in their hanging walls. In contrast, the NE-SW-striking faults are younger, as they show no evidence of Permian - Early Triassic growth, and offset several N-S- and NW-SE-striking faults. Structural analysis show that a new population of NW-SE-striking faults formed in the Lower - Middle Jurassic (inter-rift period) together with reactivation of $\mathrm{N}$-S-striking Permian - Early Triassic faults, indicating a NE-SW inter-rift extension direction.

During the Middle Jurassic - Early Cretaceous rifting, faults of all orientations (N-S, NW-SE and NE-SW) were active. However, faults initiated during the Middle Jurassic - Early Cretaceous rifting show mainly N-S orientation, indicating E-W extension during this phase. These observations suggest a reorientation of the stress field from E-W during the Permian - Early Triassic rift phase to NE-SW during inter-rift fault growth and back to E-W during the Middle Jurassic - Early Cretaceous rift phase in the Oseberg area. Hence, the current study demonstrates that rift activity between established rift phases can locally develop faults with new orientations that add to the geometric and kinematic complexity of the final fault population. 


\section{Introduction}

Many rift basins are known to have developed through multiphase rifting that comprises two or more rift phases, each of which is separated by a period of tectonic quiescence, such as the North Sea rift system (Badley et al., 1988; Færseth, 1996;

Odinsen et al., 2000a; Whipp et al., 2014), the Gulf of Aden (Lepvrier et al., 2002), the East African Rift System (Korme et al., 2004) and the North West Shelf, Australia (Frankowicz and McClay, 2010). As for the northern North Sea rift system, two rift phases are recognized: the ?Permian - Early Triassic and the Middle Jurassic Early Cretaceous rift phases (Badley et al., 1988; Bell et al., 2014; Færseth, 1996; Færseth et al., 1997; Steel and Ryseth, 1990; Yielding et al., 1992). The early consensus was that some of the faults initiated during the Permian - Early Triassic rifting were reactivated and played a significant role during the Middle Jurassic Early Cretaceous rift phase, while others were not (Badley et al., 1988; Roberts et al., 1993, 1995; Steel and Ryseth, 1990; Yielding et al., 1992). A recent study showed that reactivated Permian - Early Triassic faults interacted with newly formed faults in various styles during the Middle Jurassic - Early Cretaceous rifting, forming noncollinear fault geometries (Duffy et al., 2015). However, fault evolution during the two rift phases is not clearly understood, and particularly not the way that Permian Early Triassic faults reactivated and influenced fault growth during the second phase of rifting.

In this contribution we use $2 \mathrm{D}$ and $3 \mathrm{D}$ seismic reflection and borehole data to investigate the geometry and evolution of normal faults that evolved over the entire history of rifting in the Oseberg area in the northern North Sea. The Oseberg area is located at the boundary between the Permian - Early Triassic and Middle Jurassic Early Cretaceous rift axis (Badley et al., 1984; Færseth et al., 1997; Færseth and 
Ravnas, 1998; Tomasso et al., 2008), making it possible to study the faults related to both rift phases. The main goal is to understand the fault evolution and interaction between the two phases of rift-related faulting, and to explore what controls fault evolution in the Oseberg area and in multiphase rift basins in general.

\section{Geological setting}

The North Sea Rift System is built on originally overthickened Caledonian crust, thinned during post-collisional Devonian extension and erosion (Fossen, 2010). The Devonian, post-collisional extension resulted in the development of shear zones, such as those located onshore West Norway (Andersen \& Jamtveit, 1990; Fossen, 1992; Vetti and Fossen, 2012) and probably also in the North Sea basement (Fossen et al., 2016). Hence, the Late Paleozoic-Mesozoic North Sea rift system developed on top of a basement containing both Caledonian and Devonian shear zones (Fig. 1A) (e.g. Bartholomew et al., 1993; Glennie, 1987; Smethurst, 2000; Stewart et al., 1992; Ziegler, 1990). The Permian-Early Triassic rifting lasted for 25-37 m.y. (e.g. Ter Voorde et al., 2000; Ziegler, 1990, 1992) and was followed by 70 m.y. of relative tectonic quiescence and post-rift thermal subsidence (e.g. Bartholomew et al., 1993; Glennie, 1987; Lepercq and Gaulier, 1996; Roberts et al., 1995; Ziegler, 1990). The Middle Jurassic - Early Cretaceous rift phase (e.g. Badley et al., 1988; Coward et al., 2003; Cowie et al., 2005; Roberts et al., 1995; Underhill and Partington, 1993) led to the superimposition of rift-related extension onto the thermally subsiding basin (e.g. Færseth,1996; Roberts et al., 1995).

Rift-related normal faults in the northern North Sea strike N-S, NE-SW and NW-SE, and relate to both phases of extension (Fig. 1) (Badley et al., 1984; Bell et al., 2014; Færseth and Ravnas, 1998; Odinsen et al., 2000b; Roberts et al., 1993; Steel and 

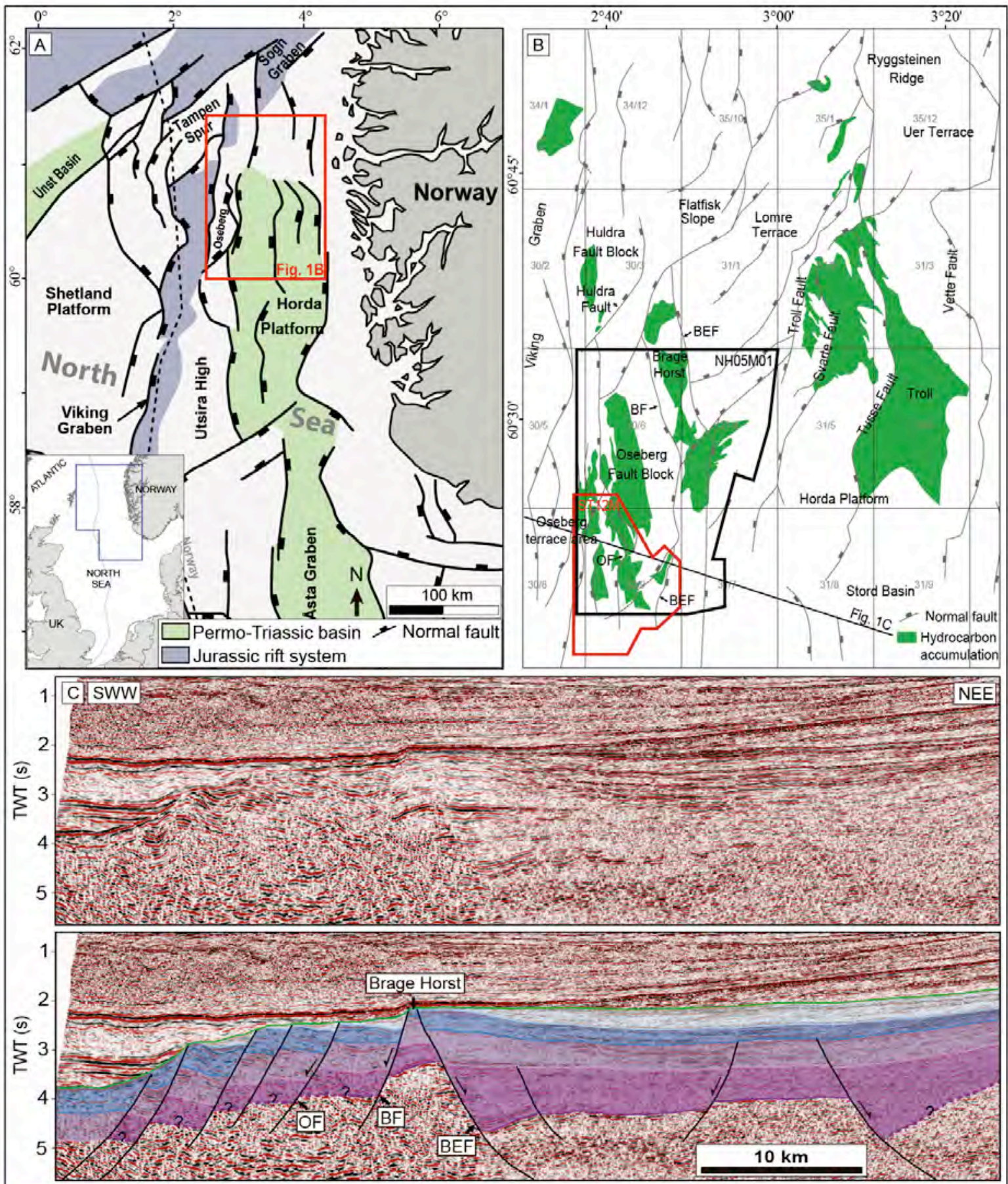

II T1 to T2 T2 to Intra-Statfjord Intra-Statfjord to Top Ness Top Ness to Base Cretaceous Unconformity - T1 - T2 Intra-Statfjord - Top Ness — Base Cretacouse Unconformity $>$ Normal fault $\sim$ Slip direction

Fig. 1. (A) Simplified structural map of the northern North Sea rift, showing areas most affected by the two rift phases. After Færseth (1996). (B) Major structural elements and hydrocarbon accumulations (green) in the Oseberg and surrounding areas, according to Norwegian Petroleum Directorate (http://www.npd.no/en/). (C) 2D line across the Oseberg area and Horda Platform. OF-Oseberg Fault, BF-Brage Fault, BEF-Brage East Fault. 
Ryseth, 1990). Permian - Early Triassic rifting is generally assumed to have occurred during $\mathrm{E}-\mathrm{W}$ extension, as indicated by the predominantly $\mathrm{N}$-S-orientation of major basin bounding and intra-basinal faults. An E-W extension direction is also supported by onshore kinematic analysis of Permo - Triassic dikes along the Norwegian rift shoulder (Fossen, 1998). Much of the Permian - Early Triassic extension was localized to the Horda Platform region (130-150 km wide), although rifting was important all across the Horda Platform - Viking Graben - Shetland Platform - West Shetland Basin area (Færseth, 1996; Odinsen et al., 2000b; Ter Voorde et al., 2000). In contrast, the Middle Jurassic - Early Cretaceous extension direction is more poorly constrained. Some authors suggest that it was coaxial with the Permian - Early Triassic rifting (Badley et al., 1988; Doré and Gage, 1987; Roberts et al., 1990) whereas others suggest WNW-ESE to NW-SE extension direction (Davies et al., 2001; Færseth, 1996; Færseth et al., 1997). The Middle Jurassic - Early Cretaceous extension is concentrated within the $25-40 \mathrm{~km}$ wide Viking Graben and the Sogn Graben (Fig. 1A) (Færseth, 1996; Odinsen et al., 2000b), while the Horda Platform itself underwent limited extension during this phase (Bell et al., 2014; Cowie et al., 2005; Færseth, 1996).

The study area is situated on the marginal part of the Horda Platform immediately east of the North Viking Graben, and comprises the Brage Horst, the Oseberg Fault Block, and the Oseberg terrace area (Fig 1B). The Brage Horst is bounded by the 80 km long E-dipping Brage East Fault to the east, and the $60 \mathrm{~km}$ long W-dipping Brage Fault to the west. The Oseberg Fault Block lies west of the Brage Horst and is bounded by the Brage and Oseberg faults in the east and west, respectively. Further to the west of the Oseberg Fault Block is the Oseberg terrace area. 
The oldest stratigraphic unit drilled in the study area is of upper Triassic age (Well 31/4-2 in Fig. 2). The Triassic Hegre Group comprises mainly continental sandstones and mudstones and is interpreted to be mainly the lower part of the inter-rift unit (Lervik, 2006; Steel and Ryseth, 1990)(Fig. 2). In the Early to Middle Jurassic, a fluvio-deltaic to shallow marine succession was deposited in the upper part of the inter-rift package that includes the Statfjord, Dunlin and Brent Groups ( Færseth and Ravnas, 1998; Helland-Hansen et al., 1992; Steel, 1993). The Middle Jurassic -

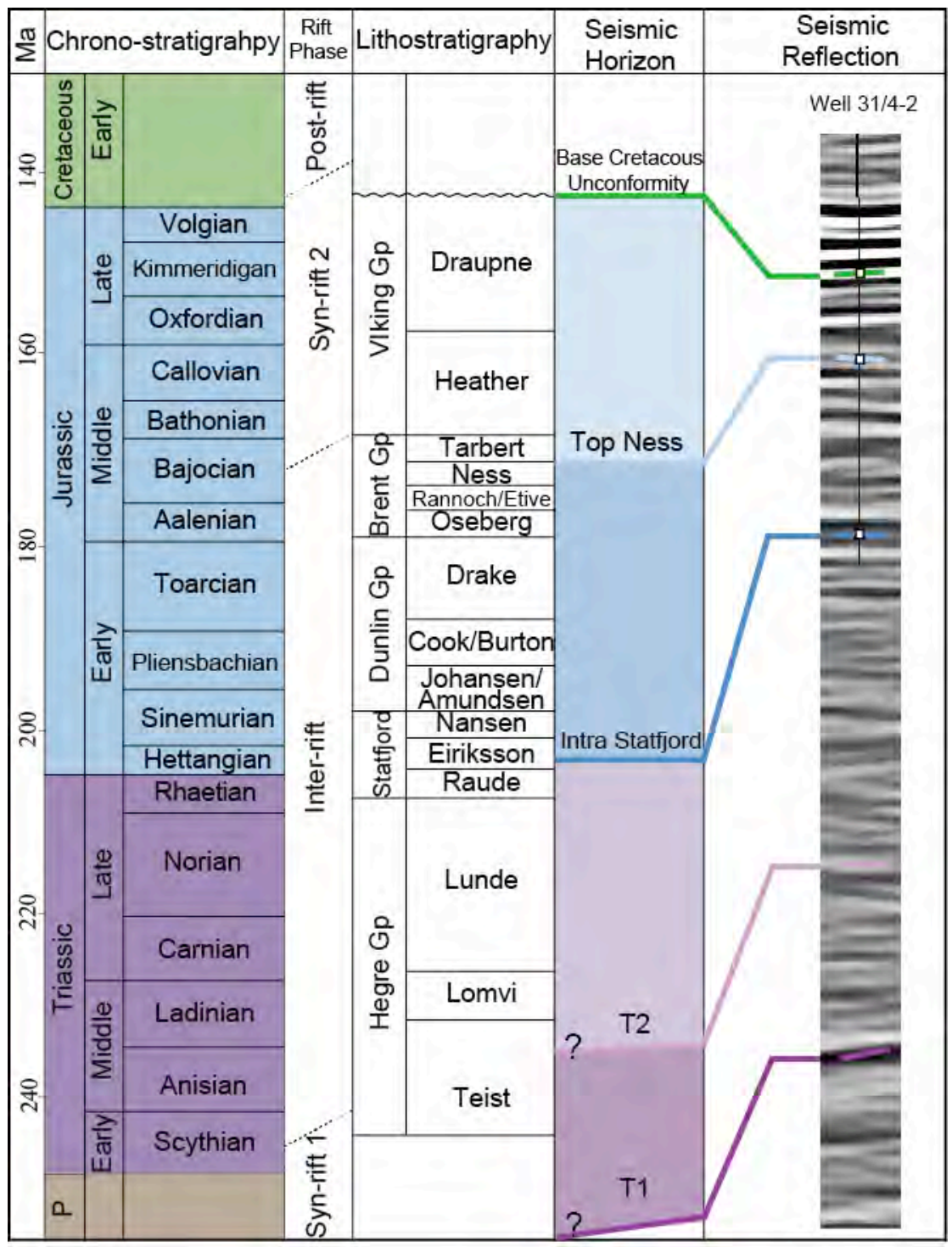

Fig. 2. Stratigraphic column in northern North Sea, after Bell et al. (2014) and Færseth (1996). The stratigraphic ages of T2 and T1 are uncertain owing to the lack of stratigraphic data from well. 
Early Cretaceous syn-rift strata are generally made up of the marine Viking Group, including shallow marine clastic sequences of the Heather Formation (Dreyer et al., 2005; Færseth and Ravnas, 1998) and deep marine mudstones of the Draupne Formation. However, in some places the initiation of Middle Jurassic - Early Cretaceous rifting coincides with the deposition of the upper part of the Brent Group (uppermost of Ness and Tarbert formations) (Helland-Hansen et al., 1992; Yielding et al., 1992). The Viking Group is capped by the Base Cretaceous Unconformity in this area which, for the most part, marks the end of the Middle Jurassic - Early Cretaceous rift Phase (Kyrkjebø et al., 2004). The Base Cretaceous Unconformity is overlain by a post-rift succession that is composed of deep-water clastics and carbonates of the Cromer Knoll and Shetland groups, and mud-dominated Cenozoic strata (Fig. 2).

\section{Data and methods}

This study is based on 2D and 3D seismic reflection data. Two 3D seismic cubes, ST12M and NH05M01 in Fig. 1B, covering the Oseberg Fault Block and Brage Horst, are used for the study. The seismic cubes cover $\sim 450 \mathrm{~km}^{2}$ and $\sim 1500 \mathrm{~km}^{2}$, respectively, with a line spacing of $12.5 \mathrm{~m}$. The cube ST12M images down to $5.5 \mathrm{~s}$ TWT, while the cube NH05M01 displays data down to $3.5 \mathrm{~s}$ TWT. The seismic is displayed in normal polarity (SEG Convention), whereby a downward increase in acoustic impedance is indicated by a peak (bright reflection) and a decrease in acoustic impedance is represented by a trough (black reflection) (Fig. 2). The 2D seismic line, striking NNW-SSE, crosses the south of the study area (Fig. 1B). In

addition, forty-six wells are tied to the seismic data by means of synthetic seismograms, covering most parts of the study area (Fig. 3). The majority of the wells 
penetrate the Brent Group, but only a few (e.g. 31/4-2 in Fig. 2) of them reach the top Triassic.

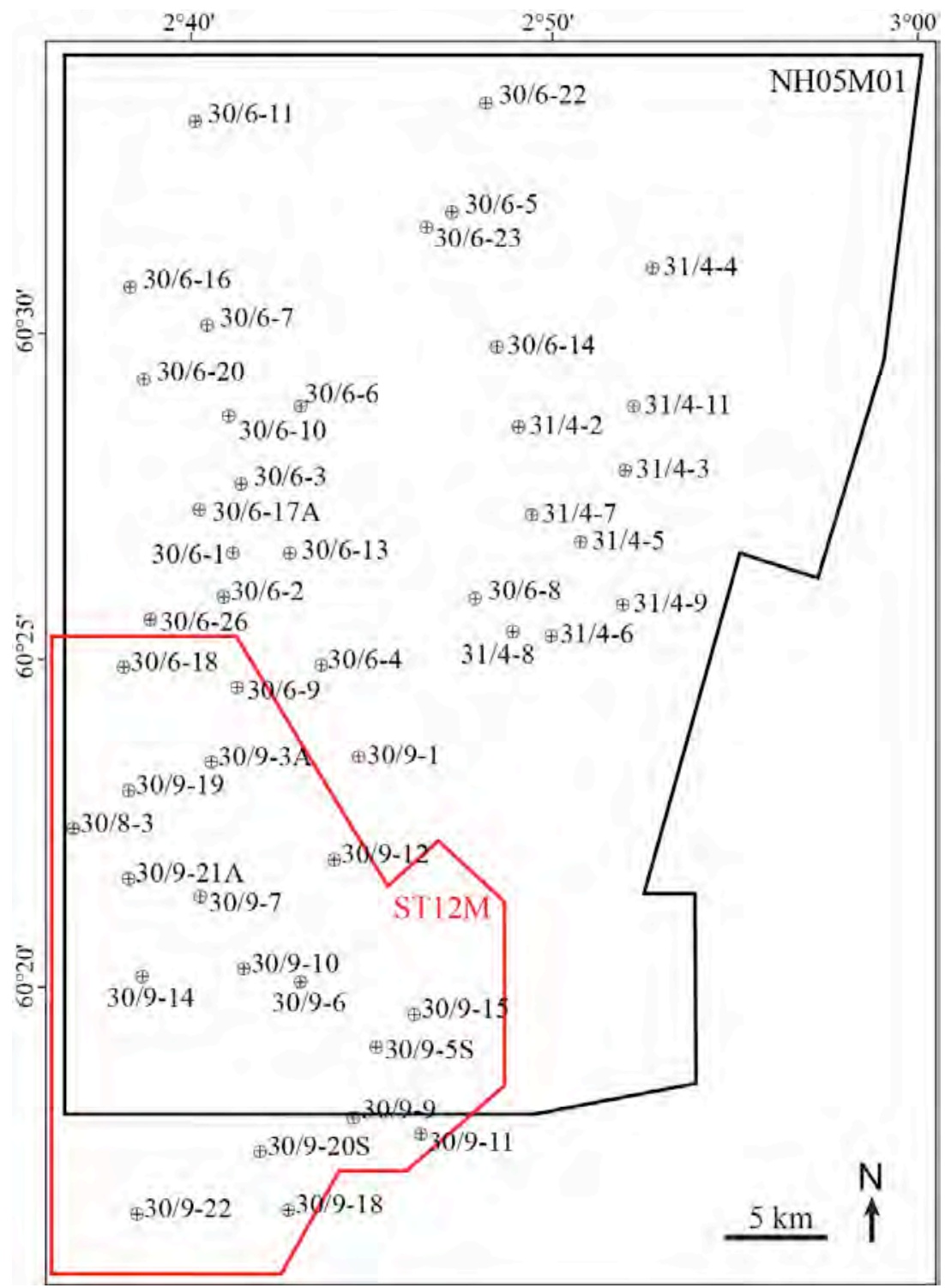

Fig. 3. Well location map in the two seismic cubes of the study area. See Fig. 1B for location.

Five seismic horizons have been interpreted: Base Cretaceous Unconformity, Top Ness, Intra-Statfjord, T2 and T1 (Fig. 2). T2 and T1 are pre-late Triassic horizons. T1 is a strong reflector deeper than $3.5 \mathrm{~ms}$ TWT in the study area, and is only mapped in the cube ST12M owing to poor or lack of data in other areas (Fig. 4A). Reflection T2 has also only been mapped in cube ST12M where it is strong in the east but relatively weak in the west of cube ST12M, in which case its interpretation is guided 
by over- or underlying reflections. Intra-Statfjord, Top Ness and Base Cretaceous Unconformity are strong and continuous reflections and mapped across the two seismic cubes (Fig. 4C-D). The horizons were interpreted at an increment of every sixteen lines $(\sim 200 \mathrm{~m})$.

Based on the seismic interpretation, we use five methods to analyze fault geometry and evolution: (i) throw-length (T-x) plots, which display fault throw for a particular horizon against the distance along the fault, and are used to study the growth and linkage of fault systems (e.g. Baudon and Cartwright, 2008a; 2008b; Cartwright et al., 1995; Dawers and Anders, 1995; Gupta and Scholz, 2000; Peacock and Sanderson, 1991; Young et al., 2001); (ii) throw backstripping that is the product of subtracting values of the shallower horizon from deeper horizons, which shows how fault propagates within the interval between the shallower and deeper horizons (e.g., Dutton and Trudgill, 2009; Morley et al,, 2007); (iii) throw-depth (T-z) profiles, which record fault throw for all interpreted horizons and yield information that can be used to interpret the vertical propagation history of faults (Baudon and Cartwright, 2008a, 2008b, 2008c; Cartwright et al., 1998; Hongxing and Anderson, 2007); (iv) strike projection of fault throw, which allows the 3D fault growth history to be investigated (Walsh and Watterson, 1991); and (v) time-thickness maps, created by calculating the difference in TWT between two horizons to tracks spatial variations in subsidence, are used to determine fault activity during those time intervals.

Fault throw, as measured on seismic sections that are oriented perpendicular to local fault strike, is the vertical distance between hanging wall and footwall cut-offs. Ductile displacement represented by fault drag was accounted for by extrapolating the reflectors to the fault along the trend of the horizon outside of the drag zone (Long and Imber, 2010; Whipp et al., 2014). Where sediment is partly or fully eroded in the 
footwall, faults and horizons were projected using local dip and stratigraphic thickness data.

\section{Structural style of the Oseberg area}

The 2D transect in Fig. 1C shows that faults are mostly E-dipping east of the Brage Horst, bounding the Permian - Early Triassic growth packages (T1 - T2 in Fig. 1C). In contrast, faults are mostly W-dipping to the west of the Brage Horst, bounding the Middle Jurassic - Early Cretaceous growth packages (Top Ness - Base Cretaceous Unconformity in Fig 1C). In map view, faults can be divided into two groups: (i) major faults that are $>20 \mathrm{~km}$ in length and show $>200$ ms TWT of maximum throw of the Top Ness horizon; and (ii) minor faults that are $<15 \mathrm{~km}$ long and show $<200 \mathrm{~ms}$ TWT of maximum throw at this level.

\subsection{Major faults}

Major faults are curved in map view, including the Brage East Fault, Brage Fault and Oseberg Fault, in addition to some faults to the west of the Oseberg Fault (Fig. 4).

\subsubsection{Brage East Fault}

The E-dipping Brage East Fault (BEF) contains three separated segments at the Intra-Statfjord and Top Ness horizons: BEF1 ( $5 \mathrm{~km}$ long) striking NNW-SSE, BEF2 ( 20 km long) striking NNW-SSE to N-S and, BEF3 ( 15 km long) striking NNE-SSW to N-S toward the south (Fig. 4). Between the three segments develop the W-dipping Brage Fault and F12, at which the segments of the Brage East Fault terminate. However, the Brage East Fault cuts through the T1 to T2 package (Fig. 5), indicating that the Brage East Fault is laterally continuous in the T1 to T2 package. In the vertical direction, the Brage East Fault tips-out at the Base Cretaceous Unconformity 


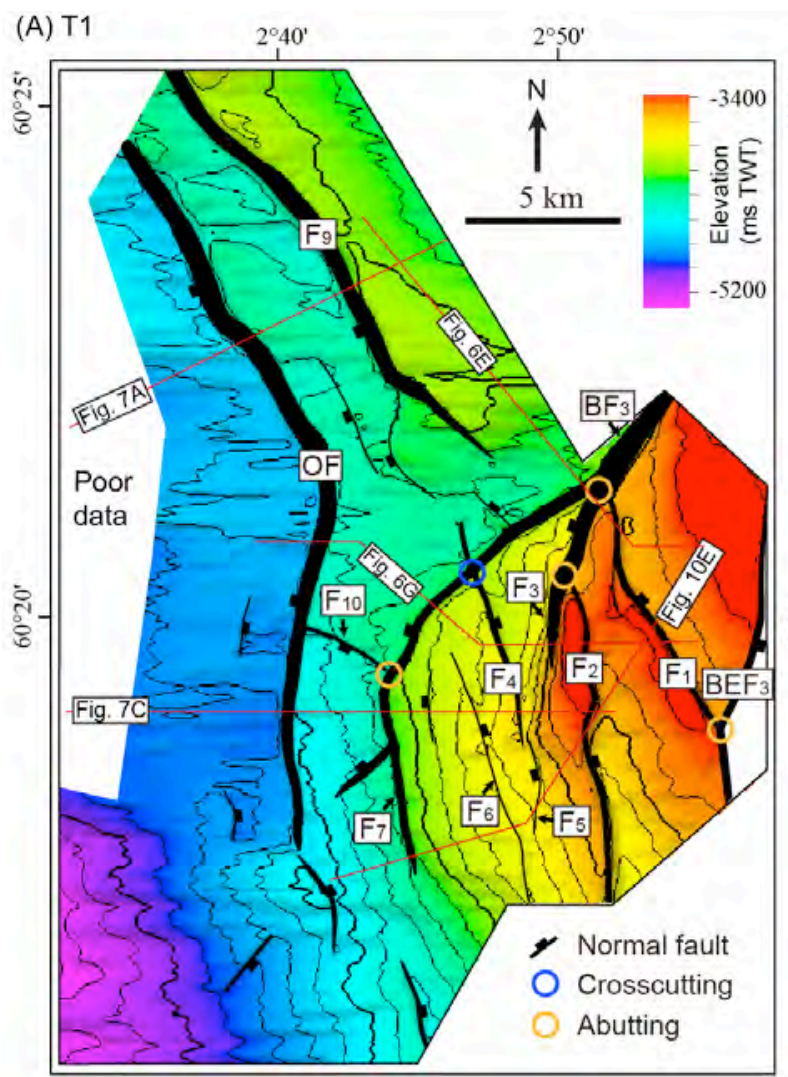

(B) $\mathrm{T} 2$

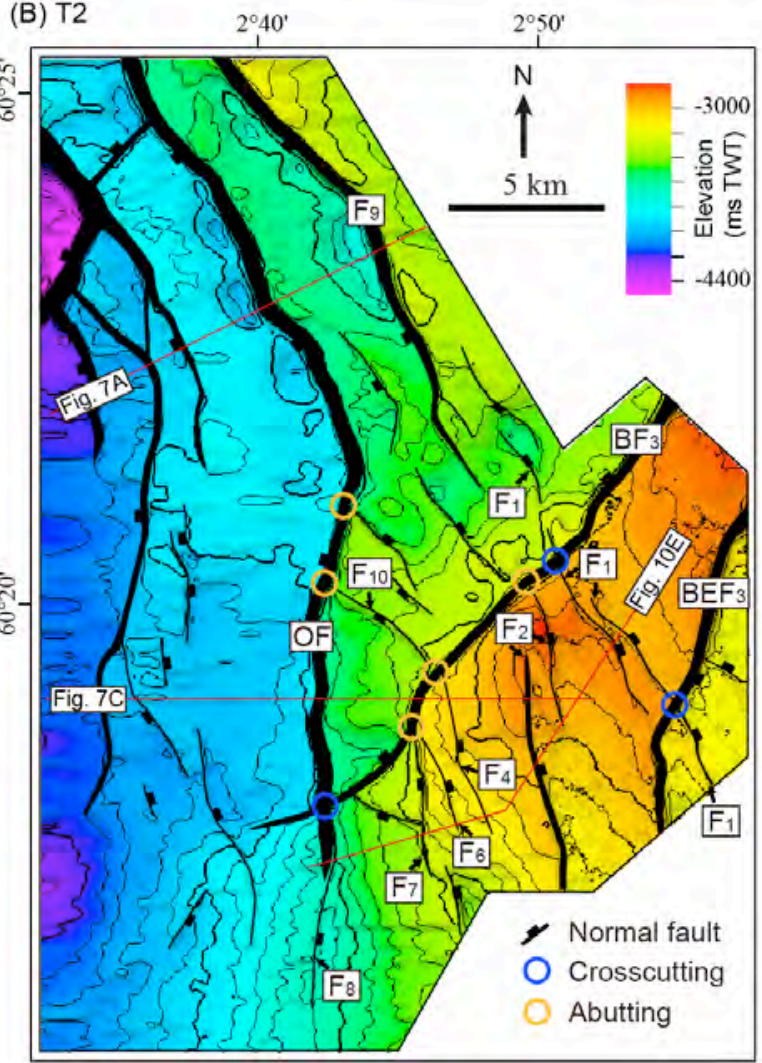

(C) Intra-Statfjord

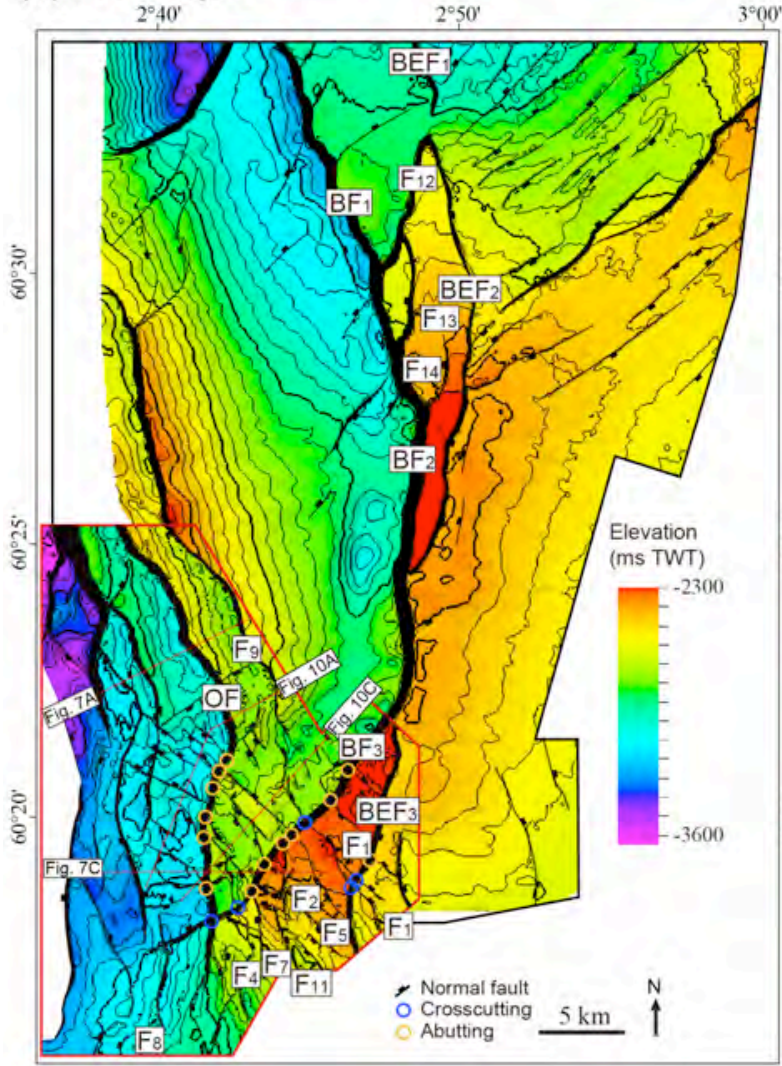

(D) Top Ness

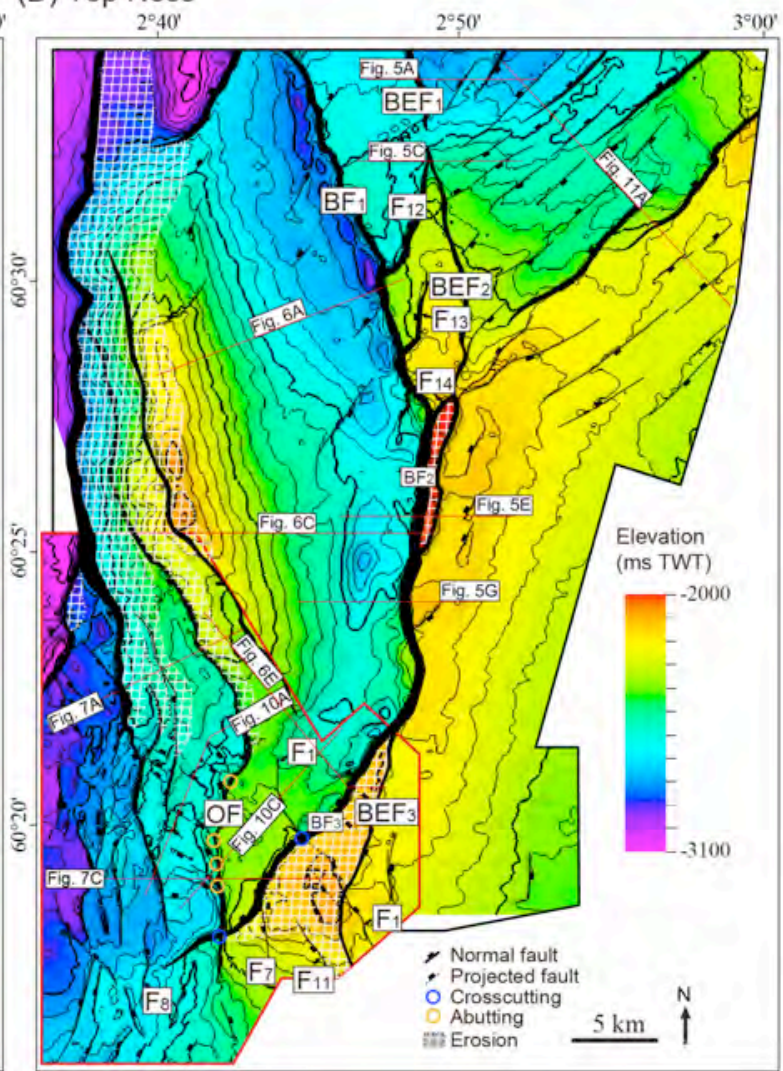

Fig. 4. TWT structure map of four key horizons. (A) T1 is a syn-rift 1 horizon. The white area which is not interpreted is owing to the poor seismic data. (B) T2, (C) Intra-Statfjord and (D) Top Ness, 
representing three horizons within the inter-rift strata, showing map view fault geometries. OFOseberg Fault, BF-Brage Fault, BEF-Brage East Fault.

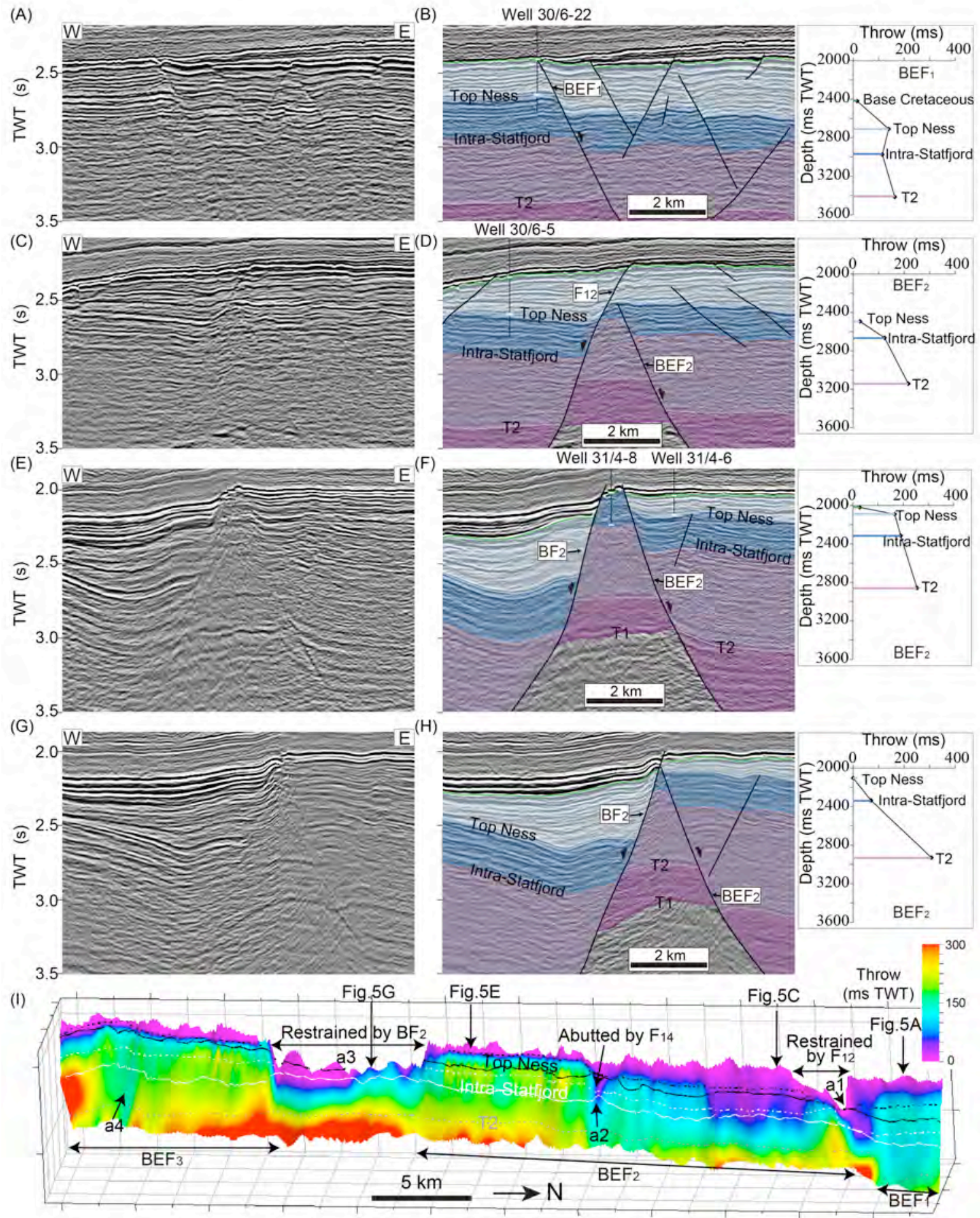

Fig. 5. Geometry of the Brage East Fault. $(\mathrm{A})-(\mathrm{H})$ are four uninterpreted and interpreted cross-sections sub-perpendicular to the Brage East Fault. See Figs. 4 and $5 \mathrm{I}$ for locations. The colors used for the key horizons and the interval between them are consistent with those used in Fig. 2. T-z plots of the 
Brage East Fault are shown in the right column. (I) Strike projection on the Brage East Fault, as viewed from the hanging-wall side of the fault. Solid lines on the fault plane are the hanging-wall cutoff lines. Dashed lines are footwall cut-off lines. 'a1'-'a4' represent throw minima or gaps.

and extends downward into the basement (Fig. 5). In the hanging wall of the Brage East Fault, the T1 to T2 package is wedge-shaped and W-expanding, whereas the T2 to Base Cretaceous Unconformity package is tabular to sub-tabular (Fig. 1C).

T-z profiles and strike projection of the Brage East Fault display a downward increase in fault throw from the Base Cretaceous Unconformity to T2 (Fig. 5). Based on the present 3D seismic data, its throw is $\sim 300 \mathrm{~ms}$ TWT $(\sim 500 \mathrm{~m})$ at the deepest mapped level (T2). The throw of the Brage East Fault at the T1 level is over $1200 \mathrm{~ms}$ TWT ( 2000 m) according to the 2D transect (Fig. 1C). Throw minima occur at locations 'a1'-'a4' on the strike projection (Fig. 5I). Specifically, the upper tip of the Brage East Fault shows a non-elliptical shape, with gaps at 'a1' and 'a3' (Fig. 5I), where it terminates in the immediate footwall of the fault F12 and Brage Fault (Fig. 5I). The 'a2' gap is related to the intersection with the fault F14, whereas 'a4' corresponds to the change in strike from N-S to NNE-SSW toward the north (Fig. $5 \mathrm{I}$ ).

\subsubsection{Brage Fault}

The whole Brage Fault (BF) is captured at the Intra-Stafjord and Top Ness horizons by the seismic cube NH05M01, displaying strike variations from NNW-SSE to N-S and then to NE-SW southward (Fig. 4C-D). For simplicity, the Brage Fault comprises

three differently-striking segments: NNW-SSE-striking BF1 ( 20 km), N-S-striking BF2 ( 15 km) and NE-SW-striking BF3 ( 20km). In cross-section, the upper tip of the Brage Fault extends upward into the Lower Cretaceous succession, and the NE-SWstriking segment (BF3) is basement rooted (Fig. 6). Clearly, the T1 to Top Ness 
package is tabular to sub-tabular, whereas the Top Ness to Base Cretaceous Unconformity package is E-expanding in the hanging wall of the Brage Fault (Fig. 6).

The segments BF1 and BF2 show a general increase in fault throw with depth (Fig. 6). Only the northern part of segment BF3 shows a slight decrease in fault throw at the T2 level (Fig. 6 I). In contrast, the southern part of the segment BF3 has a quick increase in fault throw from the Base Cretaceous Unconformity to Intra-Statfjord horizon and a slow decrease from Intra-Statfjord to T1 horizon (Fig. 6). Strike projection illustrates that the overall throw maximum of the Brage Fault is located at the central segment BF2 ( $\sim 800 \mathrm{~ms}$ TWT or $\sim 1200 \mathrm{~m})$, from where the throw decreases radially (Fig. 6G). Local sharp changes in fault throw occur at locations 'b1'-'b3' on the segment BF1, related to the intersection with faults F12-F14 (Fig. 4D).

\subsubsection{Oseberg Fault}

The W(SW)-dipping Oseberg Fault (OF) is $\sim 35 \mathrm{~km}$ long, making a bend as it turns from NNW-SSE- to N-S-striking towards the south (Fig. 4D). Vertically, the upper tip of the Oseberg Fault is located either at or above the Base Cretaceous Unconformity, and the fault extends downwards into the basement (Fig. 7). In the hanging wall of the Oseberg Fault, the Top Ness to Base Cretaceous Unconformity package is Eexpanding where not eroded, whereas the T1 to Top Ness package is tabular to subtabular (Fig. 7).

Strike projection and T-x plots of the portion of Oseberg Fault in the seismic cube ST12M shows throw minima at locations 'c1' and 'c2' (Fig. 7E, 8B). In addition, the 


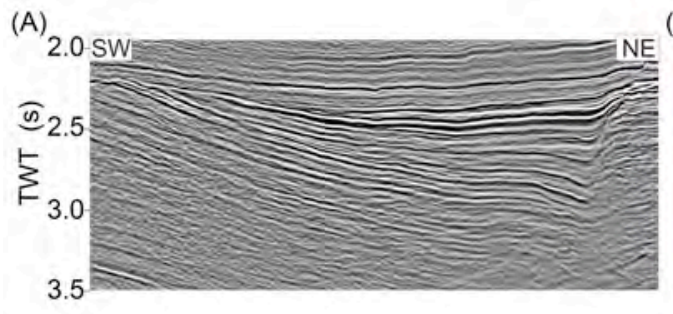

(B) Well 30/6-10 Well 30/6-6
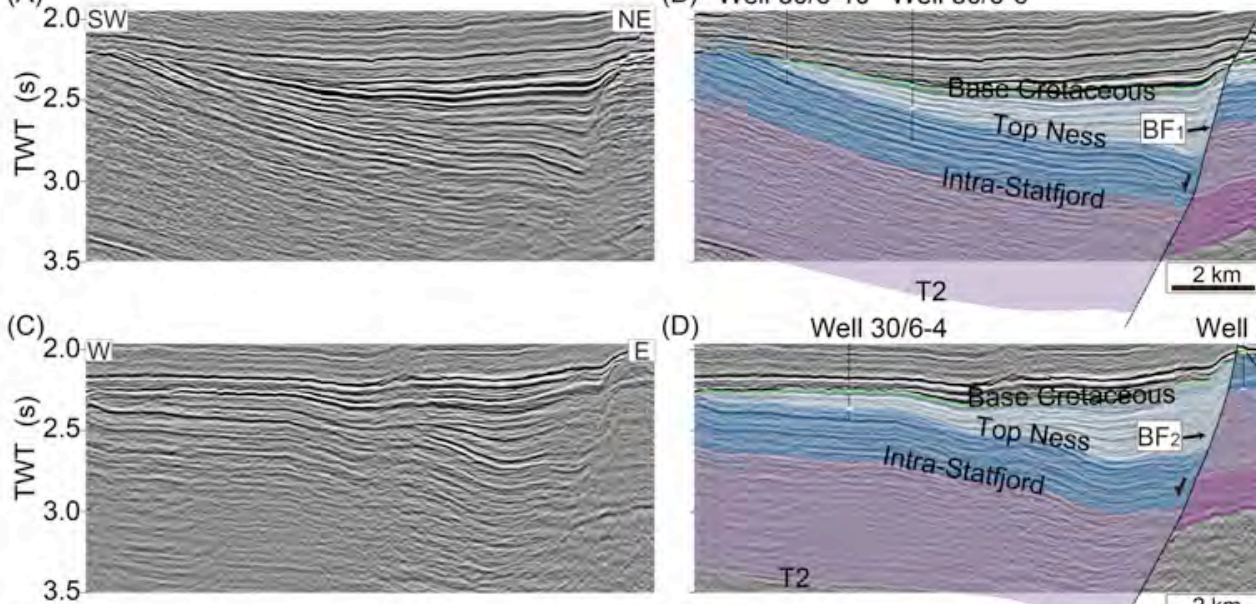

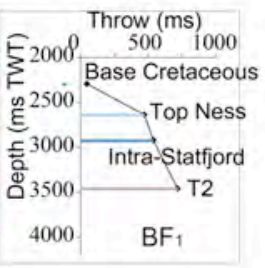

(D)
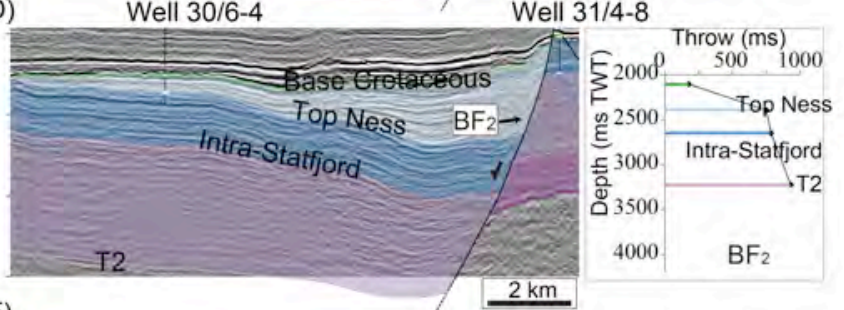

(E)

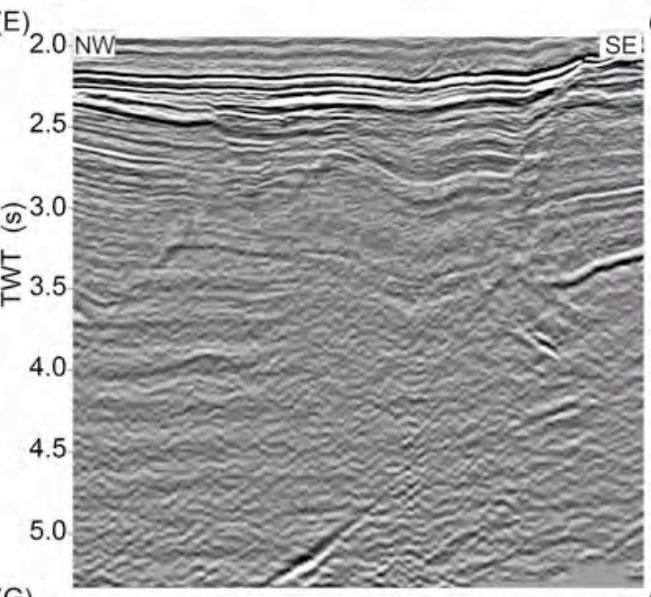

(F)
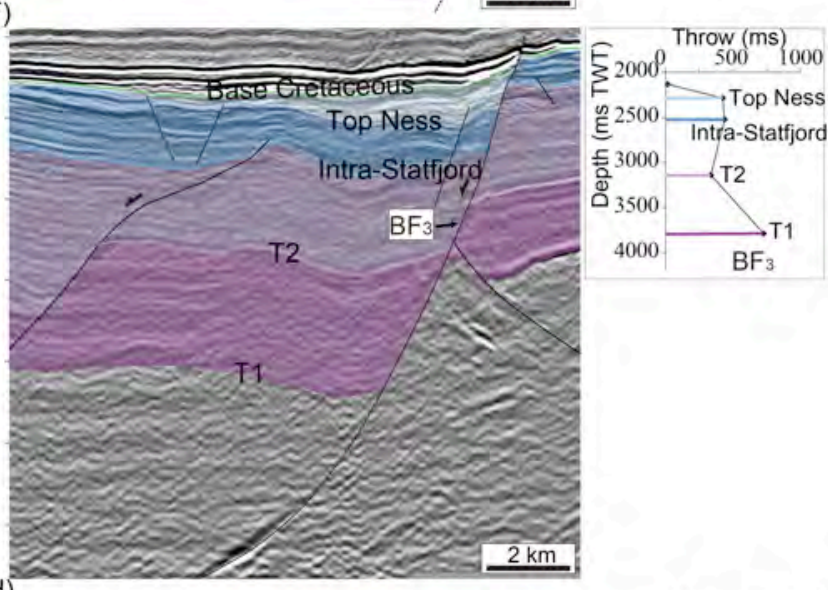

(G)

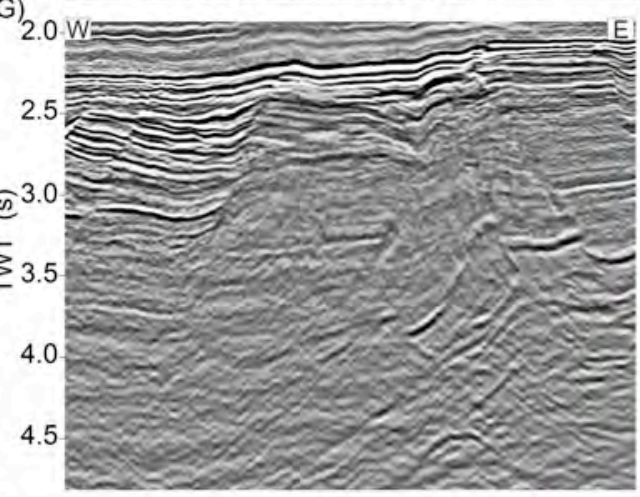

$(\mathrm{H})$

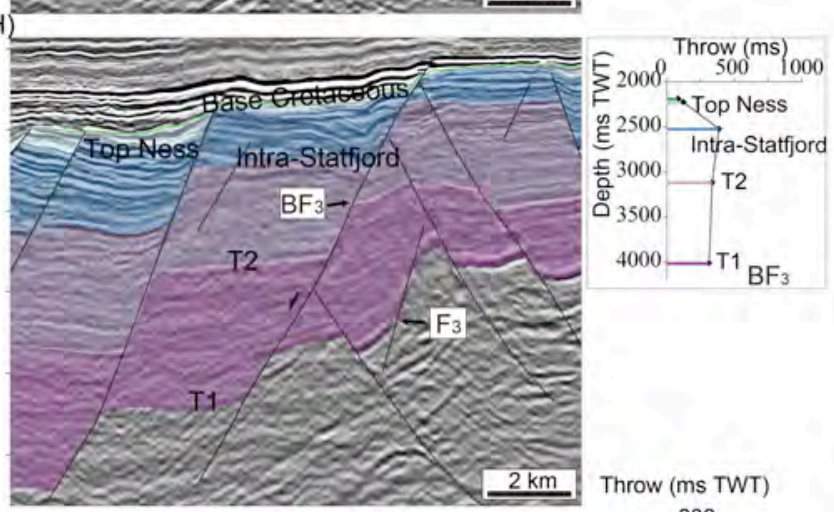

(1)

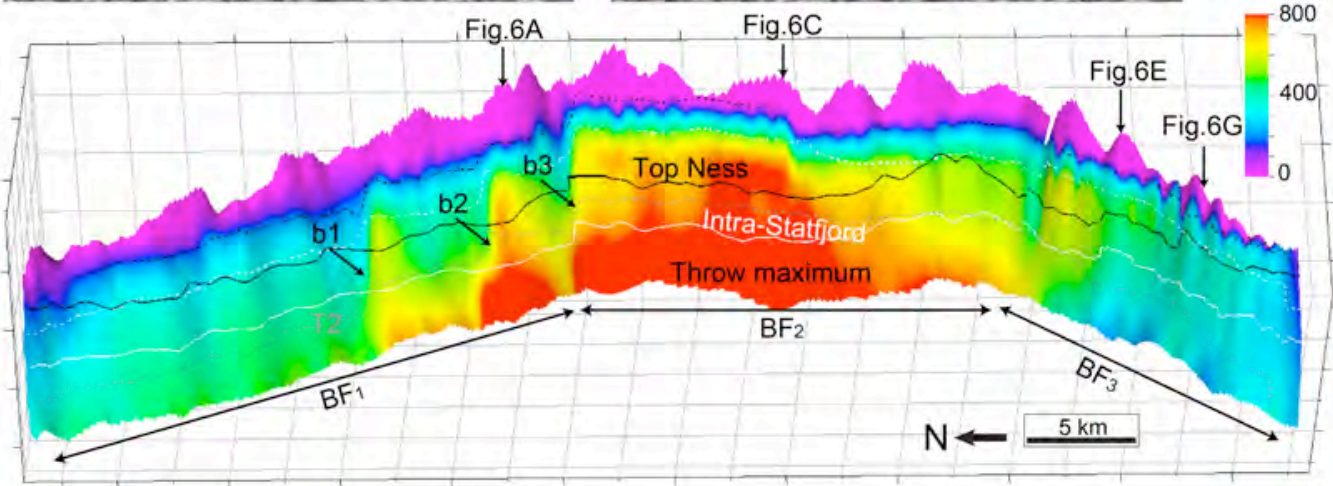

Fig. 6. Geometry of the Brage Fault. (A)-(H) are four uninterpreted and interpreted cross-sections subperpendicular to the fault local strike, across the three segments of the Brage Fault. See Figs. 4 and $6 \mathrm{I}$ 
for location of the cross-sections. The colors used for the key horizons and the intervals between them are consistent with those used in Fig. 2. T-z plots of the Brage Fault are put on the right of the interpretation. (G) Strike projection on the Brage Fault, as viewed from the hanging wall side of the fault. Solid lines on the fault plane are hanging wall cut-offs. Dashed lines are footwall cut-offs. 'b1''b3' show three locations of throw jumps on the fault plane.

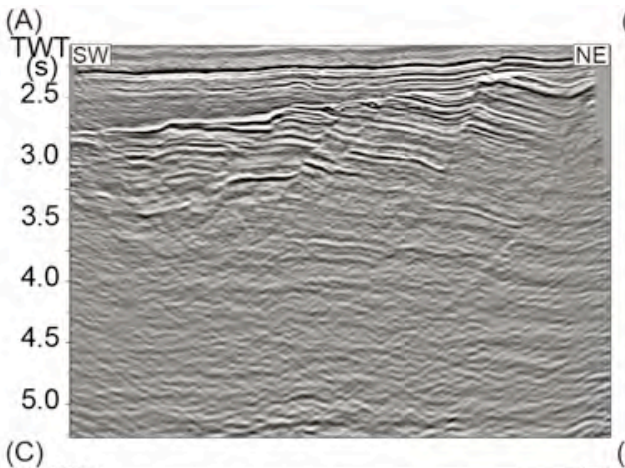

(B)
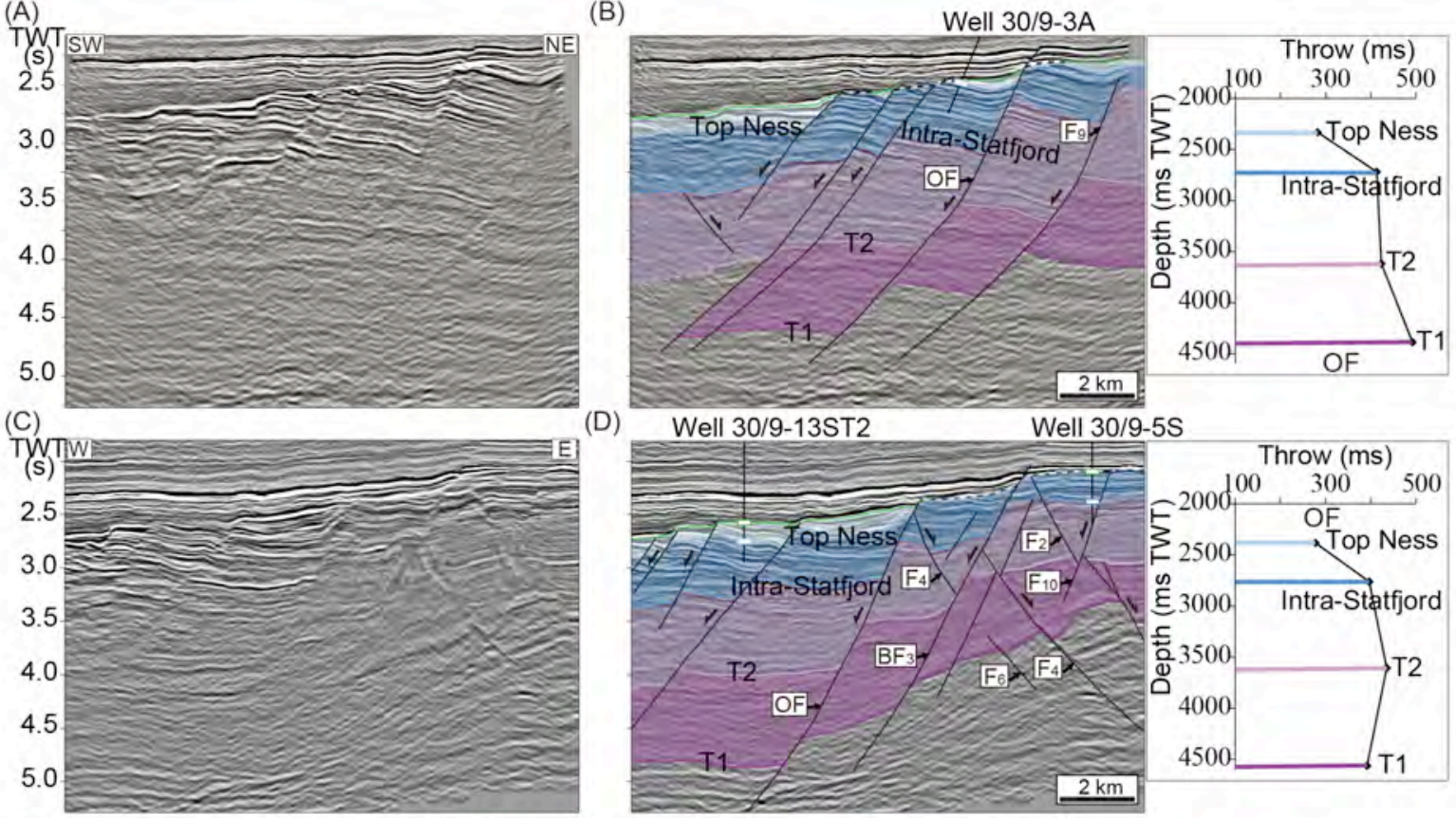

D)
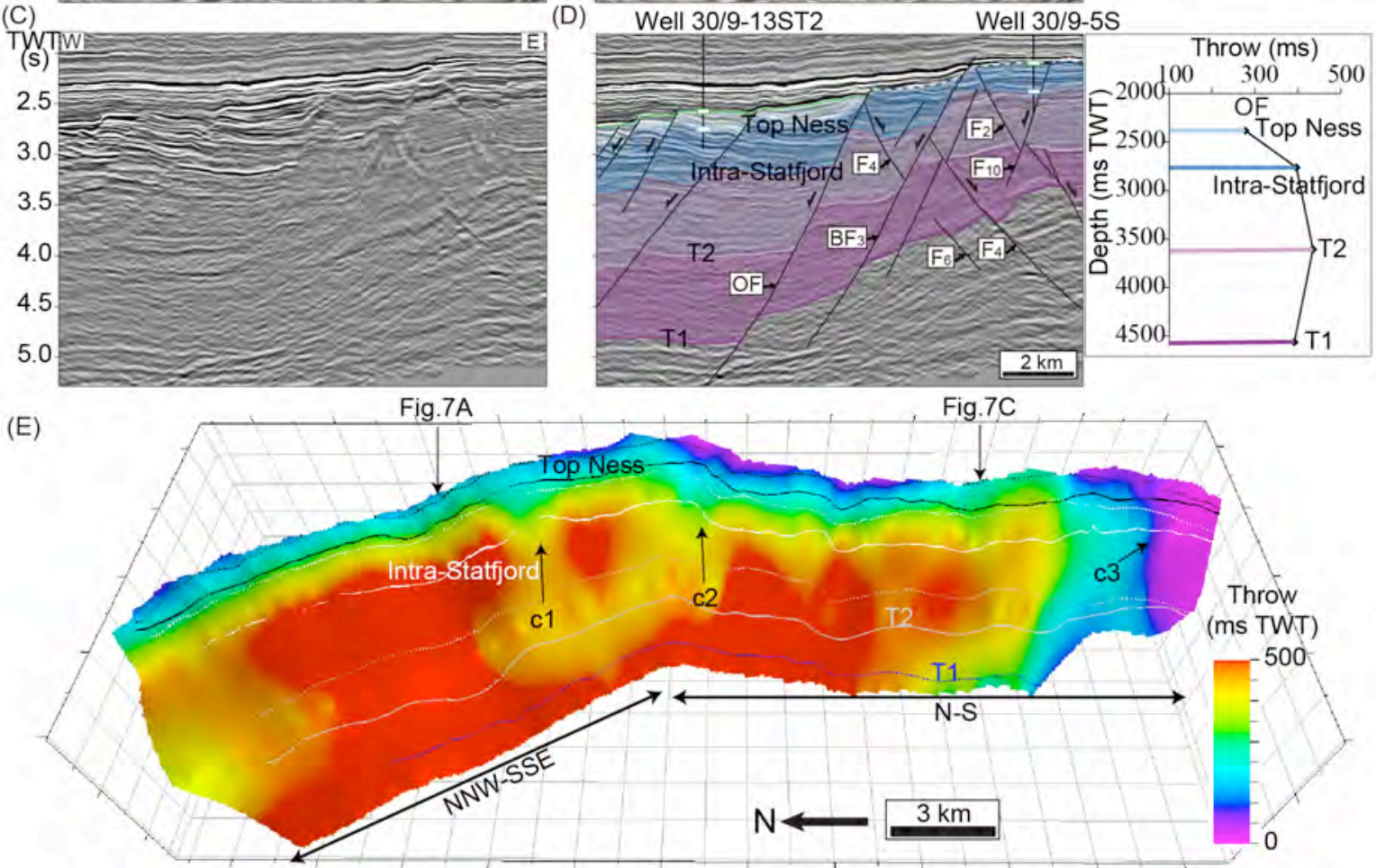

Fig. 7. Geometry of the Oseberg Fault. (A)-(D) are two uninterpreted and interpreted cross-sections sub-perpendicular to the local strike across the three segments of the Oseberg Fault. See Figs. 4 and 7E for location. The colors used for the key horizons and the intervals between them are consistent with those used in Fig. 2. T-z plots of the Brage Fault are shown in the right column. (E) Strike projection on the Oseberg Fault, as viewed from the hanging wall side. Solid lines on the fault plane are the cut-offs in the hanging wall. Dashed lines are footwall cut-offs lines. 'c1' and 'c2' show locations of throw minima. 'c3' represents the point of intersection with the Brage Fault. 


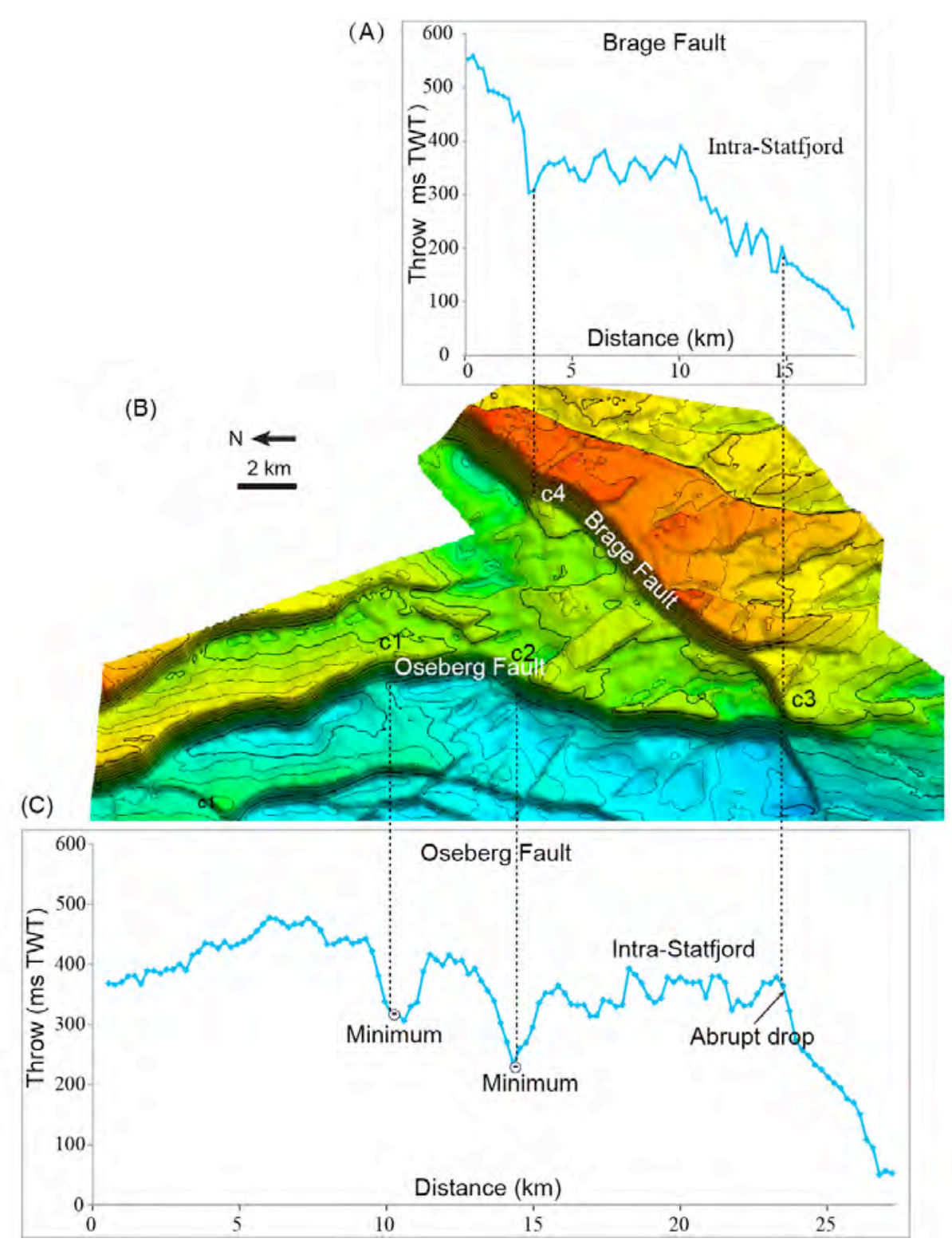

Fig. 8. T-x plots of the Oseberg Fault and the NW-SE-striking segment of the Brage Fault $\left(\mathrm{BF}_{3}\right)$ showing along-strike fault throw at the Intra-Statfjord horizon. (A) T-x plots of the Brage Fault, (B) Surface map showing the structure at the Intra-Statfjord horizon, (C) T-x plots of the Oseberg Fault. 'c1'-'c4' the location of intersection or orientation change, illustrates the corresponding position on the fault heave with T-x plots.

throw of the Oseberg Fault drops abruptly $(\sim 100 \mathrm{~ms}$ TWT or $\sim 150 \mathrm{~m})$ south of the intersection with the NE-SW-striking segment of the Brage Fault ('c3' in Fig. 8B). Vertically, the NNW-SSE-striking segment of the Oseberg Fault increases in throw from the Top Ness to Intra-Statfjord, and increases again from T2 to T1 (Fig. 7E), 
obtaining a throw value of $\sim 500 \mathrm{~ms}$ TWT $(\sim 750 \mathrm{~m})$ at the T1 horizon (Fig. 7E). In contrast, throw maximum of the N-S-striking segment is best defined at the T2 horizon and equals $\sim 400$ ms TWT $(\sim 600 \mathrm{~m})$, from where throw decreases upward and downward (Fig. 7E). In addition, throw of the horizons from Top Ness to T1 displays a rough trend of increase with depth on the NNW-SSE-striking segment of the Oseberg Fault (Fig. 9A). Back-stripping of the T-x plots shows that the fault has a maximum throw difference of $\sim 120 \mathrm{~ms}$ TWT $(\sim 180 \mathrm{~m})$ between horizons T1 and T2, $\sim 300 \mathrm{~ms}$ TWT $(\sim 450 \mathrm{~m})$ between horizons T2 and Top Ness, and again $\sim 300 \mathrm{~ms}$ TWT ( 450 m) between Top Ness and the Base Cretaceous Unconformity (Fig. 9BD).

\subsection{Minor faults}

Minor faults mainly occur in the southwest and northeast parts of the study area (Fig. 4C-D). In the southwest, minor faults are dominantly NW-SE-striking, with a few of them N-S-striking; in the northeast, they are NE-SW-striking (Fig. 4C-D).

The NW-SE-striking minor faults tip out upward in the Intra-Statfjord to Top Ness or Top Ness to Base Cretaceous Unconformity packages (Fig. 10). Growth packages are observed for the lower part of the Intra-Statfjord to Top Ness package across the NW-SE-striking minor faults in the hanging wall of the Oseberg Fault (Figs. 10B, 10G). In some cases, it is uncertain at what level the upper tips of minor faults reach, owing to the sub-Top Ness erosion (e.g. F2, F7, F10 and F11 in Fig. 10F), but some

of them, such as F4, terminate below the Top Ness level (Fig. 10D). For the lower tip, some (e.g. F1-F2 in Fig. 10F) are basement-rooted and bound a W-expanding T1-T2 package in the hanging wall; others (e.g. those in the hanging wall of F1 in Fig. 10D) tip out in the T2-Intra-Statford package, associated with an antithetic fault. In some 


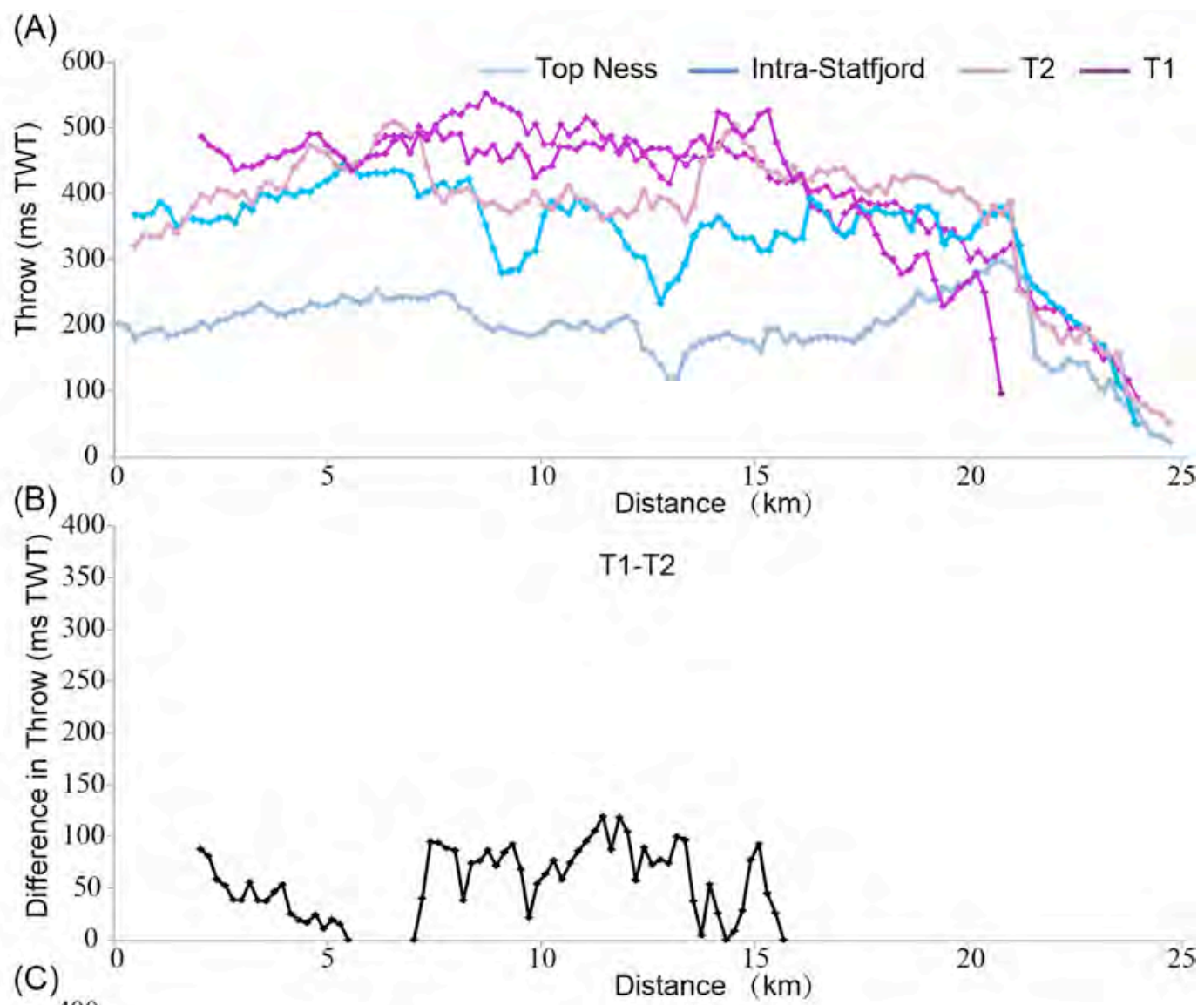

(C)

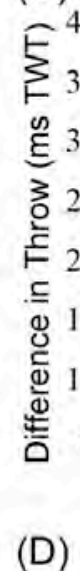

$\sum_{350}^{400}$

드 150

(D)

है 300

วิ 250

点 200

d 100

壱 50

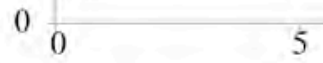

$\sum_{\models}^{400} 350$

है 300

ว 250

卢 200

드 150

ฮ 100

离 50

0

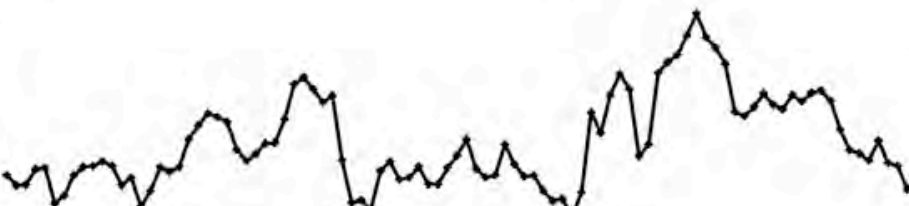

Top Ness-Base Cretaceous Unconformity

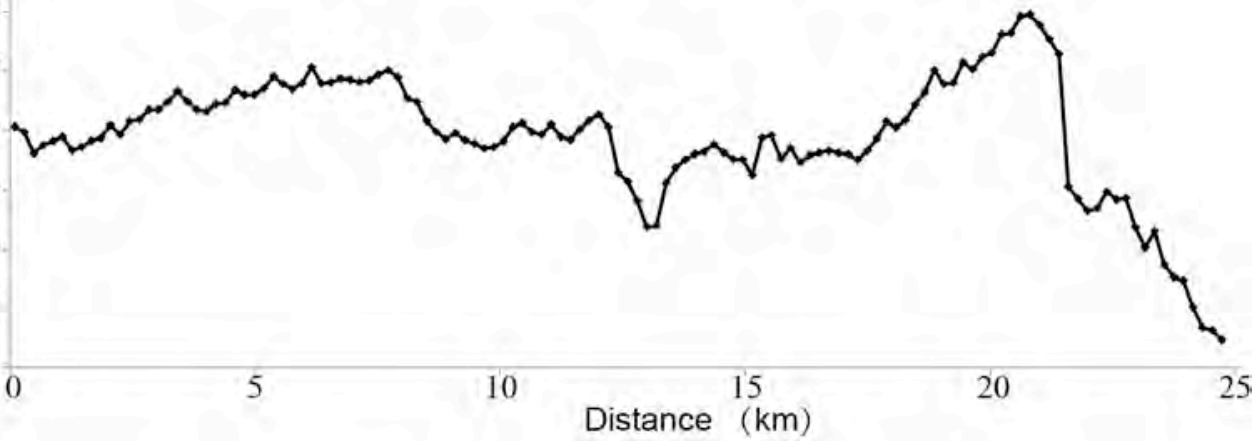


Fig. 9. (A) T-x plots of the Oseberg Fault at four horizons, show variation of fault throw along-strike and with depth. (B) The throw difference from T1 to T2 horizons. (C) The throw difference from T2 to Top Ness horizons. (D) The throw difference from Top Ness to Base Cretaceous. If the fault displays typical growth fault characteristics then the result will be a positive number and suggests fault motion during the interval, or the area lies within a part of the fault that is dying out upwards. Any negative value is displayed as zero on the figure, and suggests that that particular area of the fault only experienced displacement before or after deposition of the interval (Based on Morley et al., 2007).

cases a minor fault, such as F2, F3 or F4, is offset by the Brage Fault or another minor fault (Fig. 7D, 10D). More often, E-dipping minor faults are offset by W-dipping faults.

The NE-SW-striking minor faults generally extend upward into the Lower Cretaceous succession, and downward into the T2 to Intra-Statfjord package, with a few extending into the upper part of the T1 to T2 package (Fig. 11). Different from the NW-SE-striking minor faults, there is no obvious evidence of basement involvement for the NE-SW-striking minor faults. In addition, the Top Ness to Base Cretaceous Unconformity interval displays subtle wedge-shaped packages in the hanging wall of some NE-SW-striking minor faults, whereas the T2 to Top Ness package is roughly tabular (Fig. 11). Hence, most or all of NE-SW-striking minor faults initiated in the sedimentary rift fill.

\section{Fault evolution of the Oseberg area}

Having established the structural style of the Oseberg area, now we investigate the overall evolution of the fault network. To accomplish this, cross-sectional geometry, throw measurement and time-thickness map are integrated.

\subsection{T1 to T2 interval}


(A)

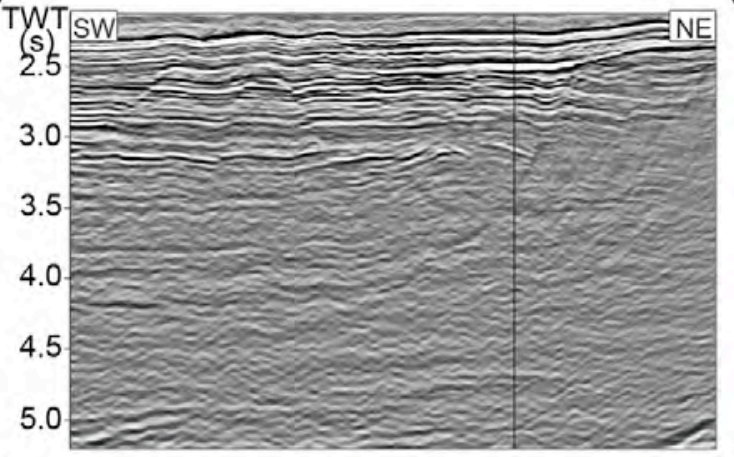

(C)

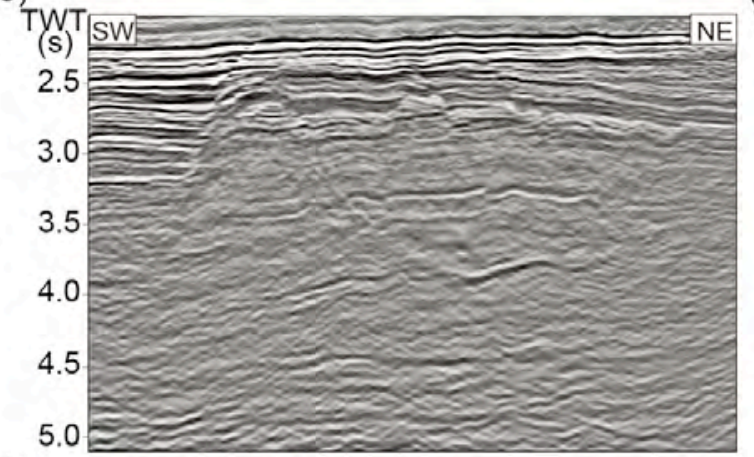

(E)

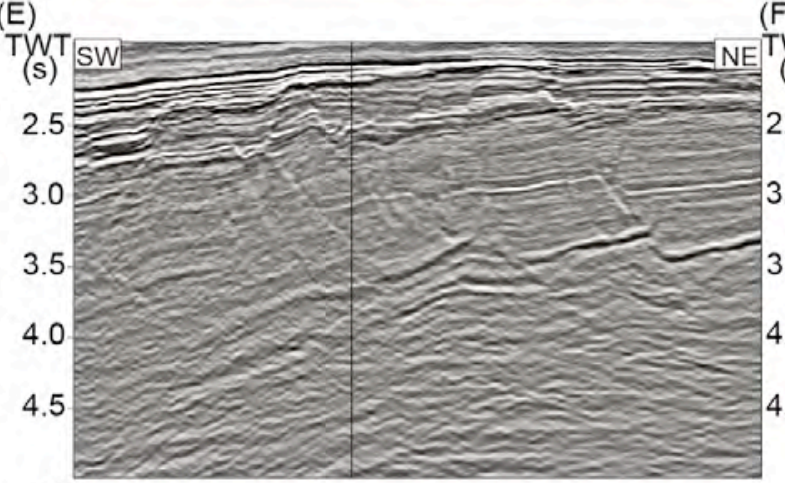

(B)

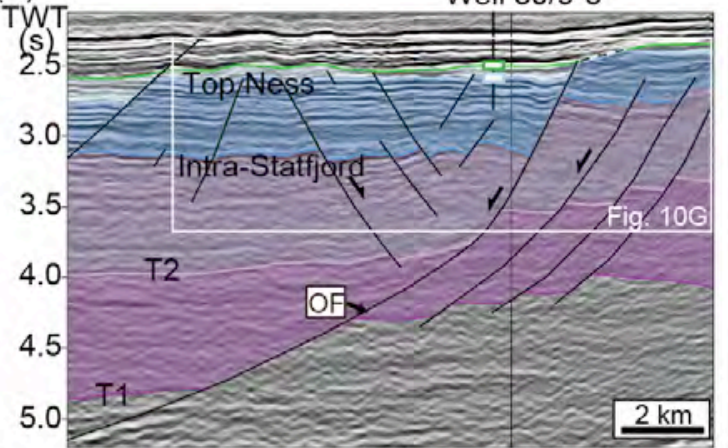

(D)

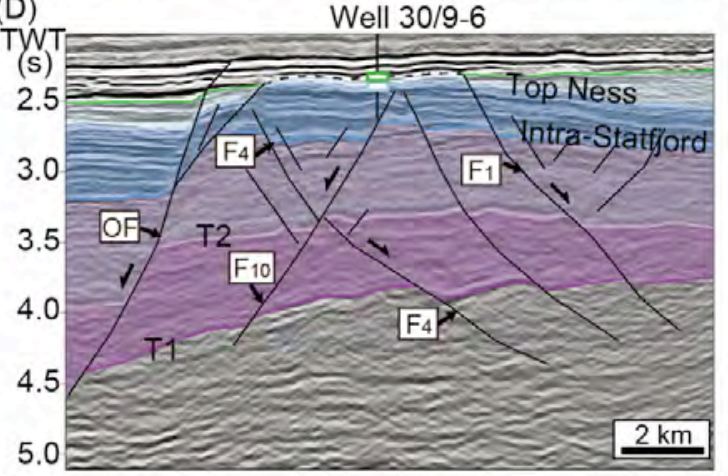

(F)

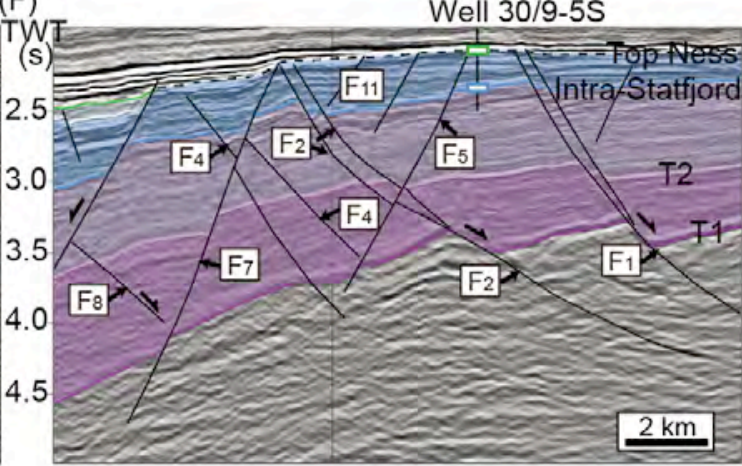

(G)

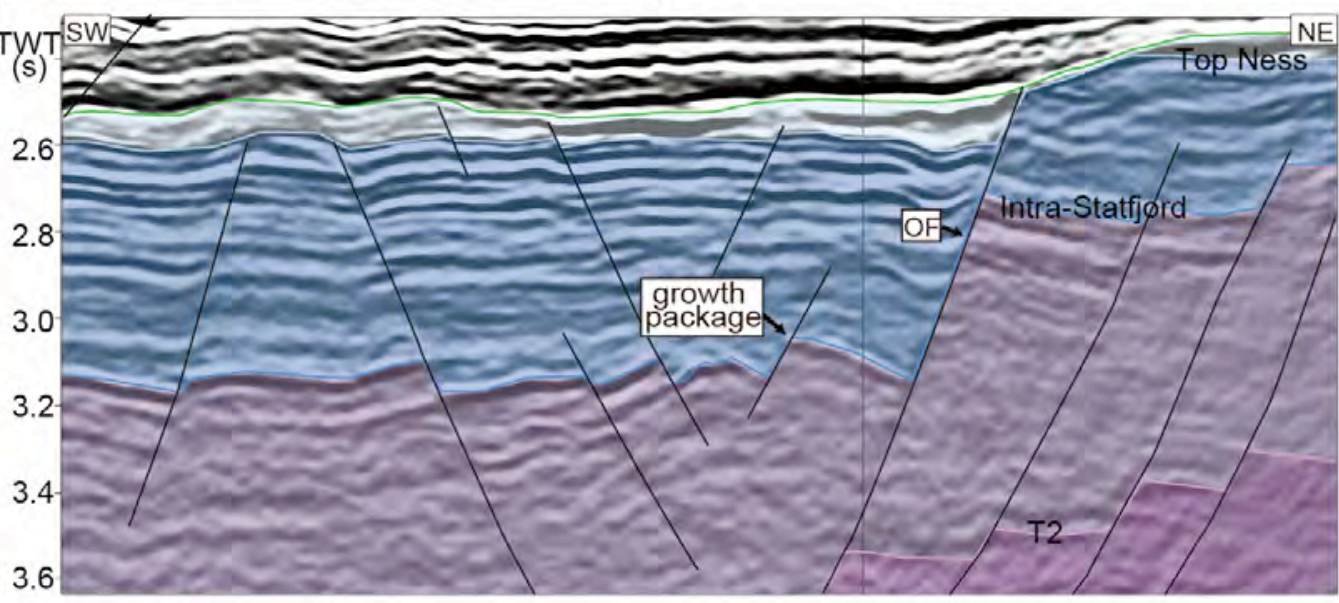

Fig. 10. Three cross-sections without (A, C and E) and with interpretation oriented sub-perpendicular to the NW-SE-striking minor faults, showing growth packages of the T1-T2 and Intra-Statfjord-Top Ness intervals in their hanging wall. The colors used for the key horizons and the interval between 
them are consistent with those used in Fig. 2. A part of the first cross-section has been enlarged (G) to show the effect of inter-rift fault activity. See Fig. 4 for location.
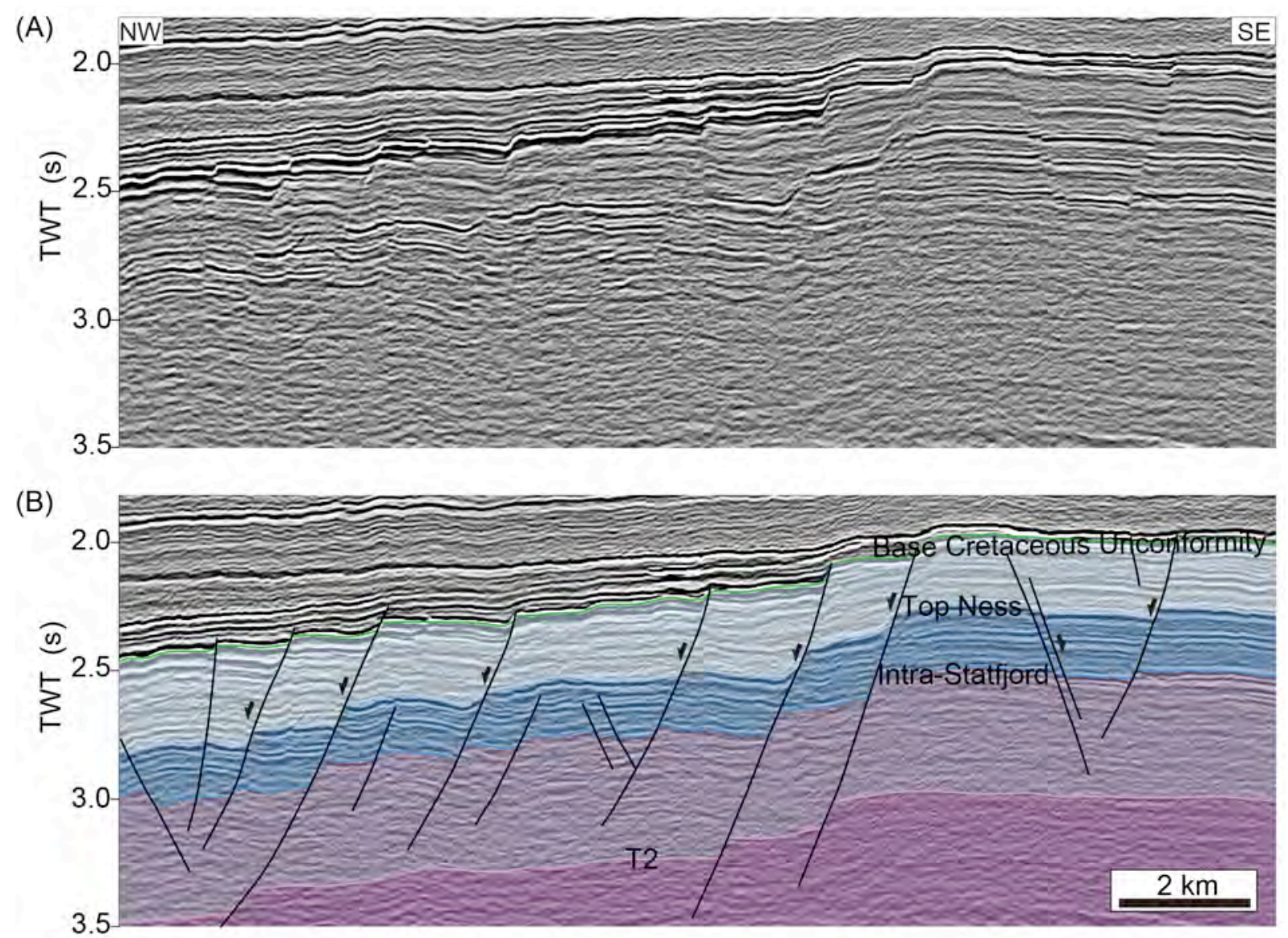

Fig. 11. Cross-section perpendicular to the trend of the NE-SW-striking minor faults. The colors used for the key horizons and the interval between them are consistent with those used in Fig. 2. See Fig. 4 for location.

Although the precise age of the T1-T2 package is unknown due to lack of borehole data, we assume, based on thickness changes and regional knowledge (e.g. Bell et al., 2015; Færseth, 1996; Steel and Ryseth, 1990) that it incorporates most or all of the syn-rift 1 package and the lower part of the inter-rift succession. Thickness increases occur across the minor faults F1 to F3, Brage East Fault (BEF3), the northern part of the NE-SW-striking segment of the Brage Fault (BF3) and the NNWSSE-striking segment of the Oseberg Fault (OF) (Figs. 7 and 12A, Tab. 1). Subtle wedge-shaped growth packages for this unit are observed in the hanging wall of F1 
and F2 (Figs. 6H, 10F), and are particular notable for the Brage East Fault (BEF3)

(Fig. 1C).
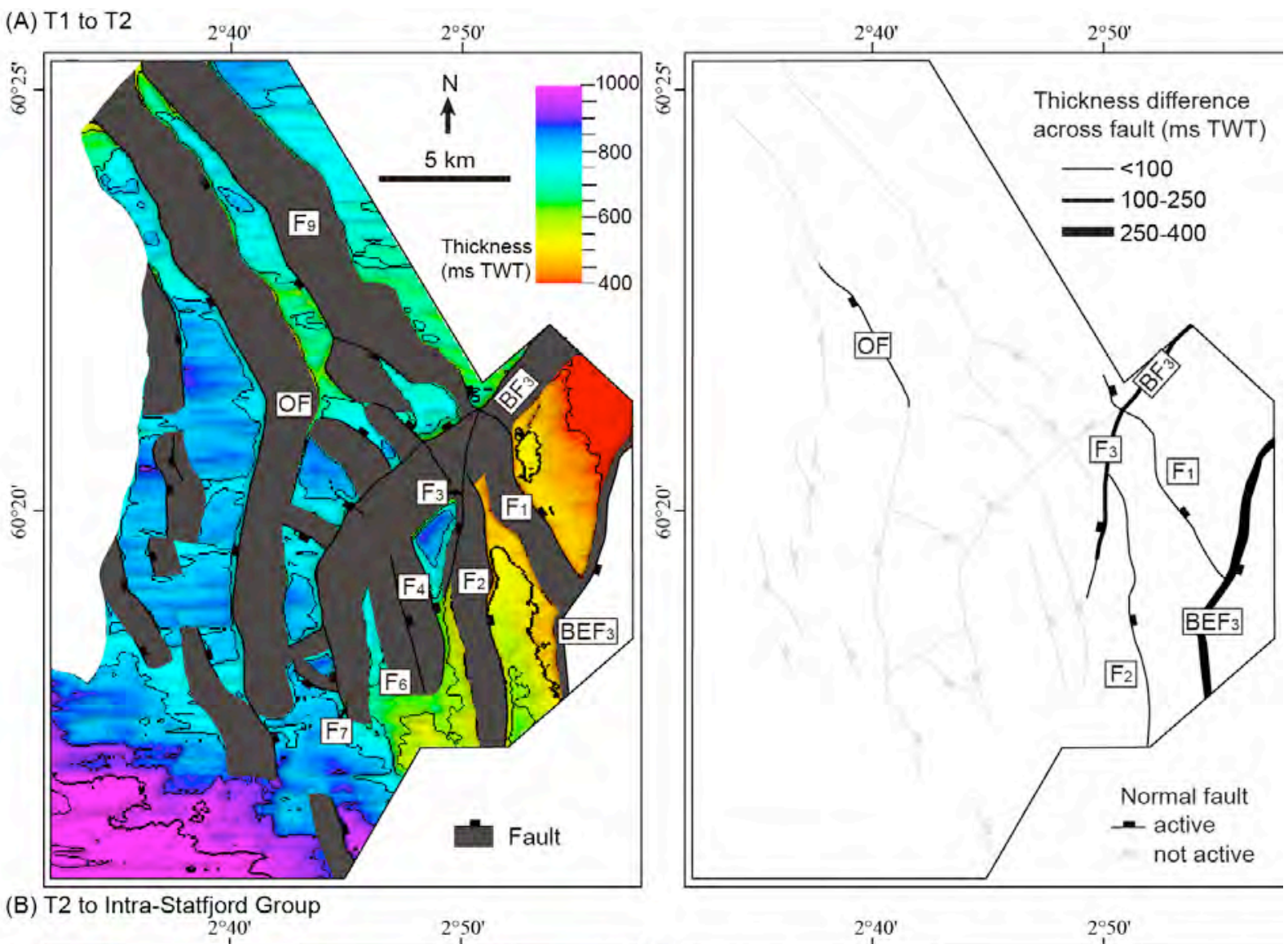

(B) T2 to Intra-Statfjord Group
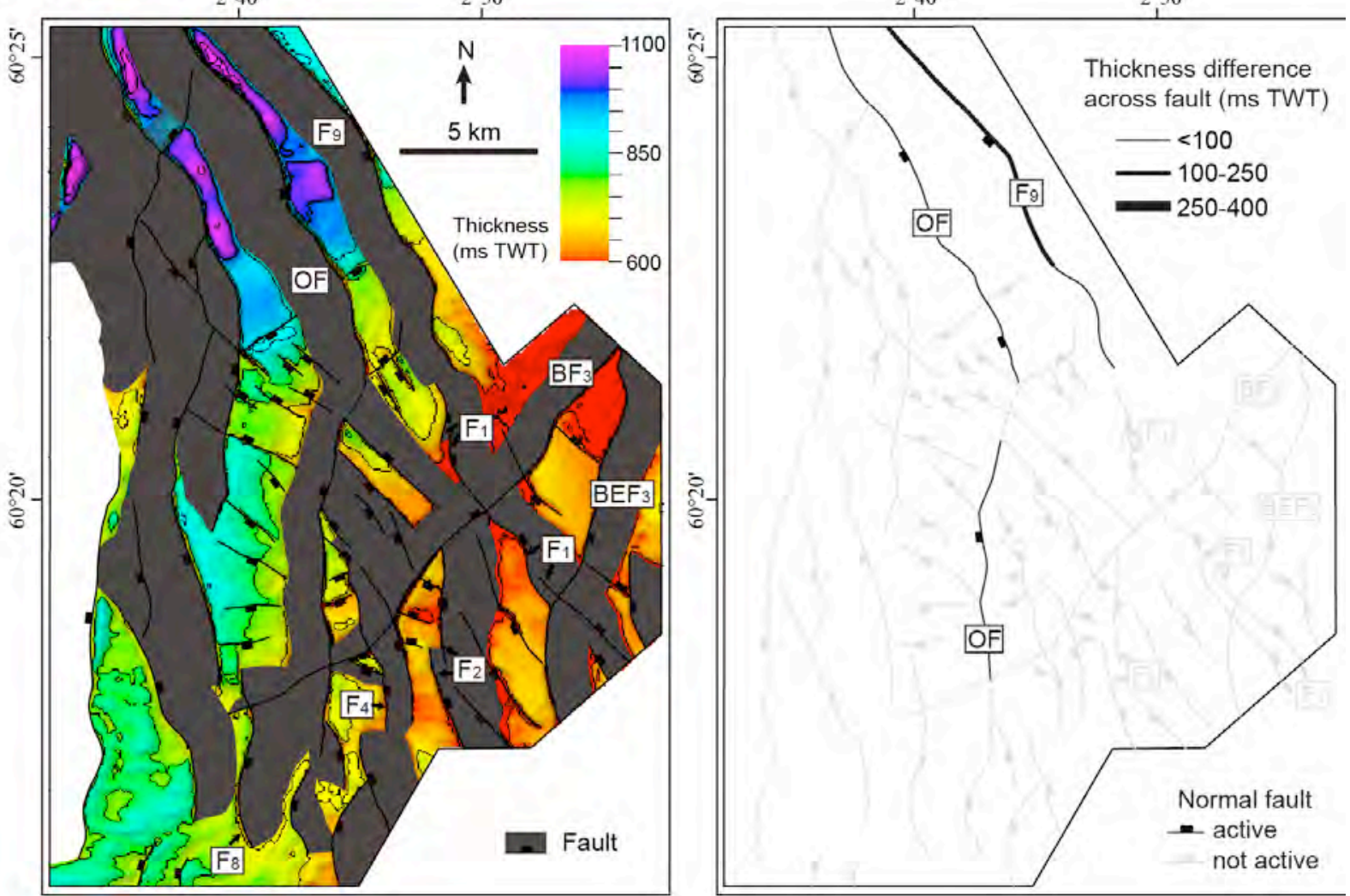
(C) Intra-Statfjord to Top Ness
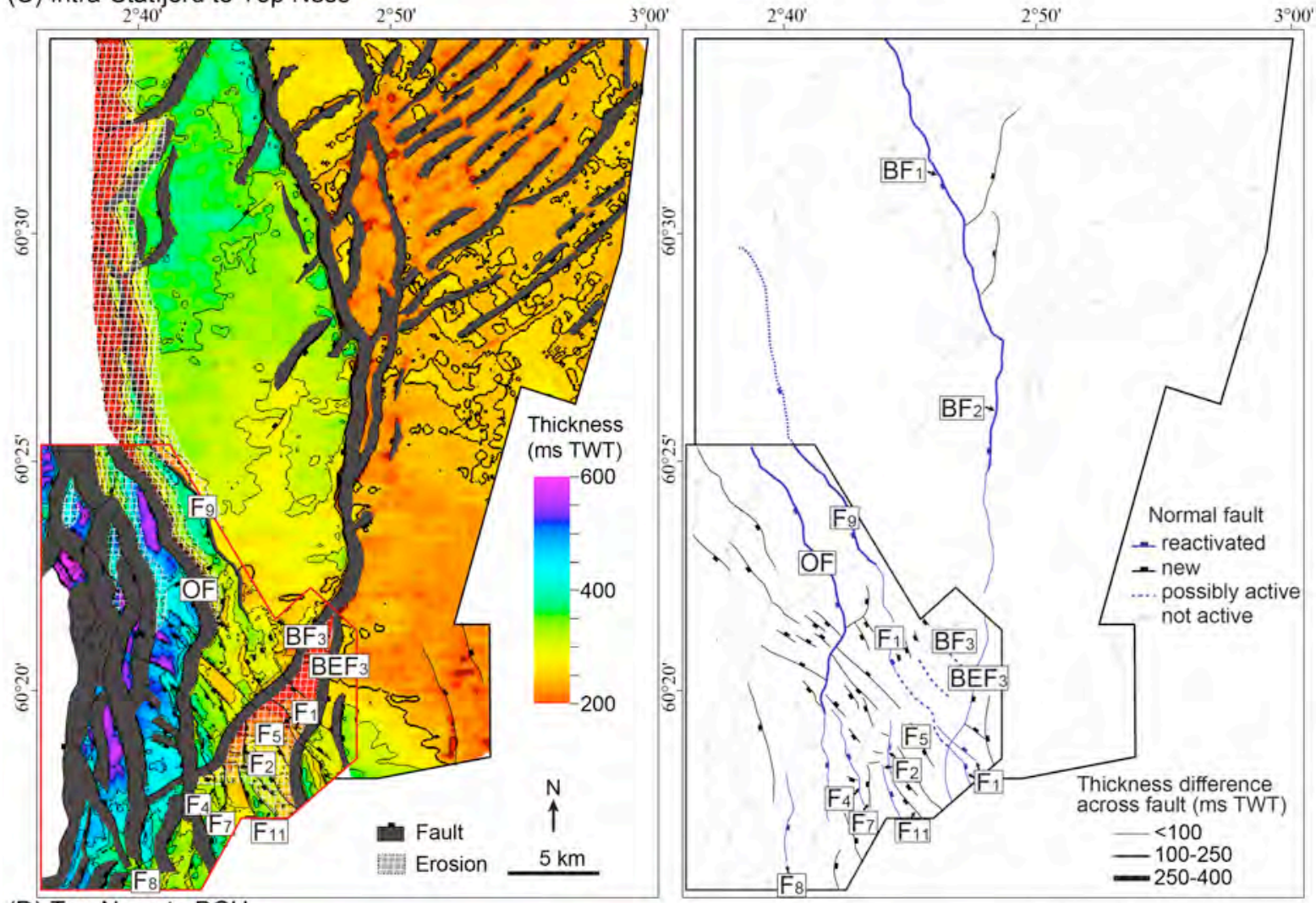

(D) Top Ness to BCU
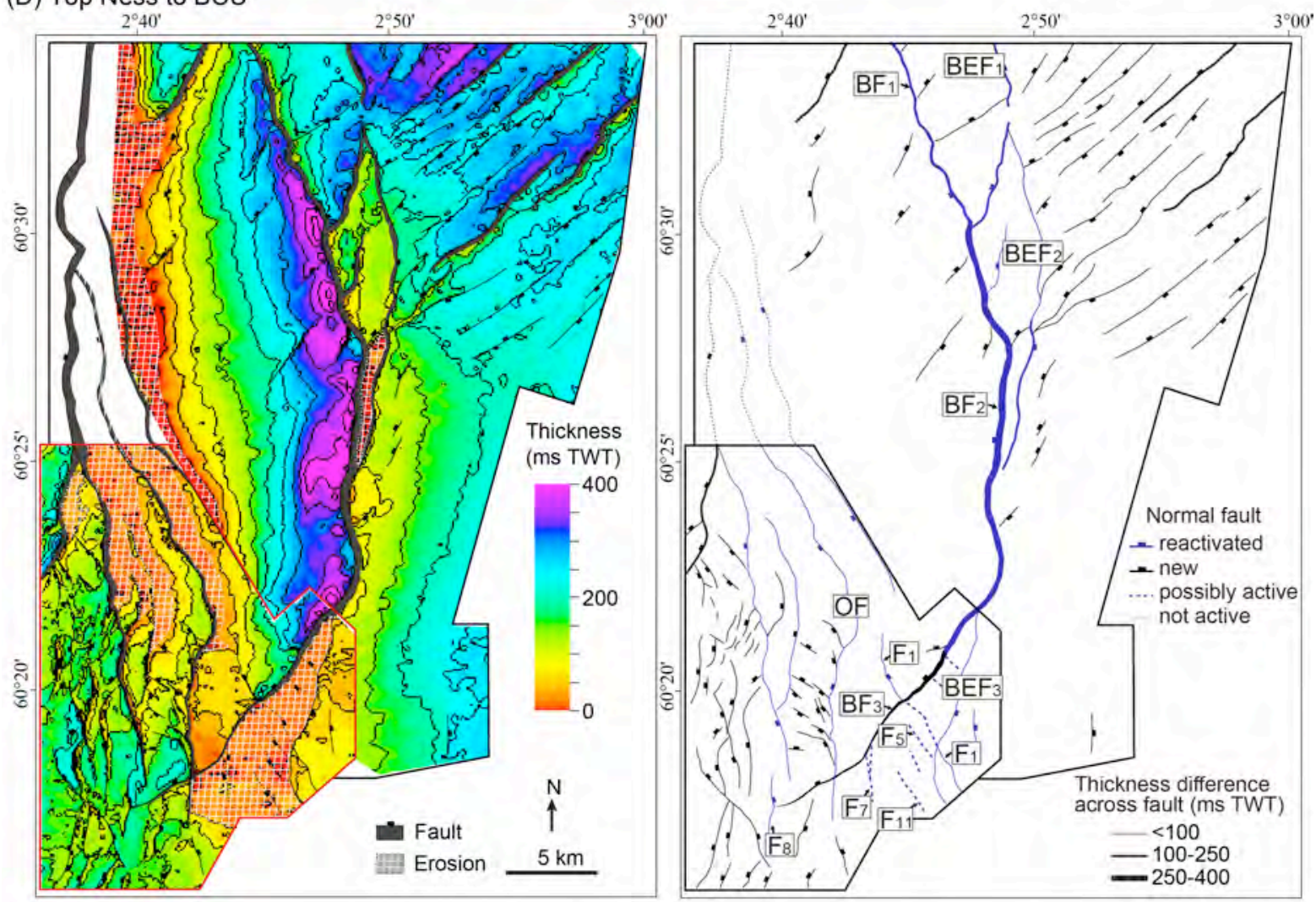

Fig. 12. Isochore maps of different time intervals showing the fault activity for each depositional period. (A) T1 to T2. (B) T2 to Intra-Statfjord. Broad gray fault polygons mark the area between the 
hanging wall cutoff of the deepest horizon and the footwall cutoff of the shallowest horizon, for which isochore values are affected by missing section. (C) Intra-Statfjord to Top Ness. (D) Top Ness to BCU, erosion of the upper part of Brent Group in the footwall crest is covered in white grid on the isochore maps. The dashed lines on Brage Horst show the location of possible active faults that were eroded in the late Jurassic.

Table 1. Thickness variations (ms TWT) across faults for each interval.

\begin{tabular}{|c|c|c|c|c|c|}
\hline & & $\begin{array}{l}\mathrm{T} 1 \text { to } \mathrm{T} 2 \\
\text { interval }\end{array}$ & $\begin{array}{l}\text { T2 to Intra- } \\
\text { Statfjord } \\
\text { interval }\end{array}$ & $\begin{array}{l}\text { Intra-Statfjord } \\
\text { to Top Ness } \\
\text { interval }\end{array}$ & $\begin{array}{c}\text { Top Ness to Base } \\
\text { Cretaceous } \\
\text { Unconformity } \\
\text { interval }\end{array}$ \\
\hline \multirow{3}{*}{$\begin{array}{l}\text { Brage } \\
\text { East } \\
\text { Fault }\end{array}$} & $\begin{array}{l}\text { NNW-SSE-striking } \\
\text { segment (BEF1) }\end{array}$ & $?$ & & & $100-250$ \\
\hline & $\begin{array}{l}\text { NNW-SSE to N-S - } \\
\text { striking segment } \\
\text { (BEF2) }\end{array}$ & $?$ & & & $<100$ or $100-250$ \\
\hline & $\begin{array}{l}\text { NNE-SSW to N-S- } \\
\text { striking segment } \\
\text { (BEF3) }\end{array}$ & $250-400$ & & $<100$ & $<100$ \\
\hline \multirow{3}{*}{$\begin{array}{c}\text { Brage } \\
\text { Fault }\end{array}$} & $\begin{array}{c}\text { NNW-SSE-striking } \\
\text { segment (BF1) }\end{array}$ & $?$ & & $100-250$ & $\begin{array}{l}100-250 \text { or } \\
250-400\end{array}$ \\
\hline & $\begin{array}{c}\text { N-S-striking } \\
\text { segment (BF2) }\end{array}$ & $?$ & & $\begin{array}{c}<100 \text { or } 100- \\
250\end{array}$ & $250-400$ \\
\hline & $\begin{array}{l}\text { NE-SW-striking } \\
\text { segment (BF3) }\end{array}$ & & & & $\begin{array}{l}100-250 \text { or } \\
250-400\end{array}$ \\
\hline \multirow{2}{*}{$\begin{array}{l}\text { Oseberg } \\
\text { Fault }\end{array}$} & $\begin{array}{c}\text { NNW-SSE-striking } \\
\text { segment }\end{array}$ & $<100$ & $<100$ & $100-250$ & $<100$ \\
\hline & $\begin{array}{l}\text { N-S-striking } \\
\text { segment }\end{array}$ & & $<100$ & $\begin{array}{c}<100 \text { or } 100- \\
250\end{array}$ & $<100$ \\
\hline \multirow{3}{*}{\multicolumn{2}{|c|}{$\begin{array}{l}\text { NW-SE-striking minor faults } \\
\text { N-S-striking minor faults } \\
\text { NE-SW-striking minor faults }\end{array}$}} & $<100$ & & $<100$ & $<100$ \\
\hline & & $<100$ & & $<100$ & $<100$ \\
\hline & & & & & $<100$ or $100-250$ \\
\hline
\end{tabular}

We interpret the minor faults F1 to F3 to have been active during the Permian - Early Triassic rifting, based on their hanging-wall wedge-shaped T1-T2 growth packages and the increase in stratigraphic thickness across them (Figs. 10F, 12A). Also, the general increase in fault throw with depth and the notable hanging-wall growth 
packages of the T1-T2 intervals indicate that the Brage East Fault formed during the Permian - Early Triassic rift phase, during which it was the largest fault in the study area (Figs. 1, 5). In addition, the general downward increase in fault throw of the NNW-SSE-, N-S- and northern part of the NE-SW-striking segment of the Brage Fault (Fig. 6) indicates that these segments probably originated from the Permian Early Triassic rift phase, despite the lack of data of the T1-T2 interval in their hanging wall. Furthermore, the NNW-SSE-striking segment of the Oseberg Fault was probably mildly active, as suggested by the thickness variations across the fault, along with the larger throw at level T1 than T2 (Figs. 9A, 12A). In contrast, the T-z profile of the N-S-striking segment of the Oseberg Fault shows no resolvable T1-T2 activity (Fig. 7). In summary, the active faults or fault segments during the T1-T2 interval strike N-S or NNW-SSE.

\subsection{T2 to Intra-Statfjord interval}

The most significant increase in thickness for the T2-Intra-Statfjord interval is observed across fault F9 (100-250 ms TWT or 150-300 m; Fig. 12B). In addition, thickness variations of up to $100 \mathrm{~ms}$ TWT $(150 \mathrm{~m})$ occur across both the NNW-SSEand N-S-striking segment of the Oseberg Fault (OF; Fig. 12B, Tab. 1). However, no resolvable thickness changes exist across other faults (Fig. 12B).

Minor faults F1-F3 and the Brage East Fault (BEF3) became inactive during the Triassic T2-Intra-Statfjord interval, as shown by Triassic T2-Intra-Statfjord hangingwall expansion across the faults (Fig. 12B). However, the Oseberg Fault (OF) appears to have been active along the NNW-SSE- and N-S striking segment, as indicated by the throw difference and thickness variations for the T2-Intra-Statfjord 
interval (Figs. 9A, 9C and 12B). Fault F9 was more active than the Oseberg Fault, judging from its larger thickness difference across F9 (Fig. 12B).

\subsection{Intra-Statfjord to Top Ness interval}

Thickness variations of up to 100 or $100-250$ ms TWT (150 or $150-300 \mathrm{~m}$; $1.3-1.5$ expansion) are observed across the major faults: the southern segment of the Brage East Fault (BEF3), NNW-SSE- (BF1) and N-S-striking (BF2) segments of the Brage Fault, Oseberg Fault (OF) and F9 (Fig. 12C, Tab. 1). Furthermore, thickness changes of $<100$ ms TWT (150 m; 1.1-1.4 expansion) occur across numerous NWSW- and N-S-striking minor faults in the southwest of the study area (Fig. 12C, Tab. 1). In cross-section, subtle wedge-shaped growth packages develop in the lower part of this unit across NW-SE-striking minor faults in the hanging wall of the Oseberg Fault (Fig. 10G).

We interpret the N-S- and NNW-SSE-striking segments of the Oseberg Fault to have linked up during this Early - Middle Jurassic time interval as the thickness increase is now also seen in the linkage area between the two segments (Fig. 12C). In addition, stratigraphic thickness variations show that the southern segment (BEF3) of the Brage East Fault and the NNW-SSE- (BF1) and N-S-striking (BF2) segments of the Brage Fault were active (Fig. 12C). For the same reason, a number of NW-SEstriking together with a few N-S-striking minor faults developed in the southwestern part of the study area (Fig. 12C). Similar to the T2-Intra-Statfjord interval, most of the strain was localized to the NNW-SSE-striking segments of the Oseberg and Brage faults. Hence, the Oseberg Fault, the NNW-SSE- (BF1) and N-S-striking (BF2) segments of the Brage Fault continued to be active during the Early - Middle 
Jurassic time interval, together with the initiation of a population of NW-SE-striking minor faults.

\subsection{Top Ness to Base Cretaceous Unconformity interval}

The Top Ness-Base Cretaceous Unconformity interval are different from the underlying T2-Intra-Statfjord interval in four ways. First, N-S-striking minor faults show thickness changes of up to $100 \mathrm{~ms}$ TWT (150 m; 1.2-1.45 expansion) in the southwestern end of the study area (Fig. 12D). Second, thickness changes start to occur across the NE-SW-striking minor faults in the northeast of the study area, mainly less than 100 ms TWT (150m; 1.2-2.0\% expansion). Third, the Brage Fault displays a thickness change of $>250 \mathrm{~ms}$ TWT (300 m; 5.28 expansion) across the central N-S-striking segment (BF2), decreasing laterally to the north and the south. Finally, thickness changes of up to 100 or $100-250$ ms TWT (150 m or $150-300$ m; 1.4-4.65 expansion) appear across the Brage East Fault (Fig. 12D).

The Top Ness to Base Cretaceous Unconformity interval represents the partly eroded syn-rift 2 package. It is obvious that some of the NW-SE-striking minor faults that formed during the previous interval (see above) remained active during the Middle Jurassic - Early Cretaceous rift phase since they offset the Top Ness horizon (Fig. 4D). However, a few NW-SE-striking minor faults between the NE-SW-striking segment of the Brage Fault and the Oseberg Fault became inactive, such as F4 which terminates in the footwall of the major Oseberg Fault (Fig. 10D).

All the segments of Brage East Fault were active during the Middle Jurassic - Early Cretaceous rift phase, with the upper tip propagating into the Top Ness to Base Cretaceous Unconformity interval (Figs. 5, 12D). However, the gaps at locations 'a1' and 'a3' on the plane of the Brage East Fault imply that the upper tip of the Brage 
East Fault is retarded at the intersection with the oppositely dipping F12 and Brage Fault (Fig. 5I). Therefore, the upward growth of the reactivated Brage East Fault was retarded where intersecting with oppositely dipping faults. That is the reason why the upper portion of the Brage East Fault exhibits an irregular, non-elliptical geometry in three dimensions, having some separated segments at the upper level that join into a single deep root at the bottom (Figs. 4C-D).

The Oseberg Fault has been a long-lived fault from its initiation during the Permian Early Triassic rift phase, followed by a period of growth during the Middle TriassicMiddle Jurassic, with renewed growth during the Middle Jurassic-Early Cretaceous rift phase, as suggested by the thickness variations during each of the two rift phases and the time interval between them (Fig. 12).

The southern part of the NE-SW-striking segment of the Brage Fault (BF3) started to grow during the Middle Jurassic - Early Cretaceous rift phase, based on the thickness variations, Top Ness - Base Cretaceous Unconformity wedge-shaped growth package and downward decreasing fault throw from the Intra-Statfjord to T1 horizons (segment BF3 in Fig. 6I, 12D). Similarly, the NE-SW-striking minor faults in the northeast of the study area formed. In addition, the NE-SW-striking segment of the Brage Fault (BF3) cuts through the T1-T2 growth package and offsets F4, demonstrating that this segment terminated or developed after the active history of F4 (Fig. 7D). The significant thickness increase and growth package of this unit in the hanging wall of the Brage Fault indicate that it became the dominant fault during the Middle Jurassic - Early Cretaceous rift phase (Figs. 6, 12D). In comparison to the Intra-Statfjord to Top Ness interval, the main deformation migrated from the NW-SEstriking faults to the N-S-striking segment of the Brage Fault (BF2) and the NE-SW- 
striking minor faults during the Middle Jurassic - Early Cretaceous rift phase (Fig. 12D).

\section{Discussion}

\subsection{Fault activity during the inter-rift phase}

It is generally assumed that the Middle Triassic - Middle Jurassic inter-rift phase in the northern North Sea was a period of tectonic quiescence and post-rift thermal subsidence (Badley et al., 1988; Færseth, 1996; Odinsen et al., 2000a; Roberts et al., 1993; 1995; Steel, 1993; Yielding et al., 1992). This assumption implies that Permian

- Early Triassic faults were tectonically inactive, although thickness change across these faults may still have occurred due to differential compaction over the buried rift topography, particularly in the earliest post-rift stage. However, we found numerous faults that were active during the late stage of the inter-rift phase, especially in the Intra-Statfjord to Top Ness time interval (Fig. 12C). The Oseberg Fault, for instance, accumulated a throw of up to $\sim 300$ ms TWT $(\sim 400 \mathrm{~m})$ during the inter-rift phase, equal to that during the Middle Jurassic - Early Cretaceous rift phase (Fig. 9C, 9D). The throw difference from the T2 to Top Ness horizon means that the amount of deformation of the Oseberg Fault during the Middle Triassic - Middle Jurassic time interval is comparable to that of the Middle Jurassic - Early Cretaceous rift phase. Also, our observations suggest that fault activity was significant and variable during the late stage of the inter-rift phase, with wedge-shaped growth packages in the hanging walls of the NW-SE-trending minor faults (1.1-1.4 expansion; Fig. 10). Such growth packages are not likely to be the result of thermal subsidence alone, and we suggest that the later stage of the inter-rift phase experienced relatively strong tectonic stretching. The newly formed faults during this stage are quite straight in 
map view and consistently NW-SE-trending, independent of their nearness to preexisting faults (Fig. 12C). Hence, they seem to be the result of Early Jurassic NE-SW extension.

Minor fault block rotation and local variation in subsidence rates across major fault zones has been postulated to occur locally in the Aalenian of the Middle Triassic Middle Jurassic stage, e.g. in the East Sherland Basin and on the Horda Platform in the northern North Sea (e.g., Færseth \& Ravnås, 1989; Nøttvedt et al., 1995; Steel \& Ryseth 1990). Ravnås et al. (2000) suggested that the subsidence was caused partly by minor extension stages. They also suggested referring to the Middle Triassic Middle Jurassic succession as inter-rift instead of post- or pre-rift. Our work found the evidence of fault activity associated with tectonic stretching during this stage, such as thickness variations and minor growth packages in the associated succession, thus reinforces the assumption by Ravnås et al. (2000). Also, we suggest that fault activity during the interval between the two main phases of rifting was, at least in the Oseberg area, of comparable magnitude to that during the main rift phases. This study implies that the tectonic influence on Middle Triassic - Middle Jurassic inter-rift succession in the northern North Sea needs further attention with respect to basin evolution and infill history.

\subsection{Changes in extension direction during multiphase rifting}

During the Middle Jurassic - Early Cretaceous rift phase, N-S-, NW-SE- and NE-SWstriking faults were active, suggesting that the extension direction varied temporally and/or laterally during this time interval. The newly formed faults during this interval were N-S-striking in the westernmost part of the Oseberg area (Fig. 12D), but NESW-striking in the northeastern part (Fig. 12D). Therefore, the late Jurassic extension 
direction appears to have been E-W in the western part and NW-SE in the northeastern part of the Oseberg area, assuming that the extension direction is perpendicular to the strike of new-formed faults and that the faults are close to dip slip (Anderson, 1951). However, the dominant Brage Fault, with a N-S strike on average across the area and the main displacement accumulated on its N-S-striking central segment, indicates a general E-W extension direction. While normal faults with different orientations can form simultaneously during none-plane strain (e.g., Healy et al., 2015), crosscutting relations indicate that the NE-SW-striking segment of the Brage Fault developed later than the N-S- and NW-SE-striking faults (Fig. 7D), which suggests a change in extension direction from E-W to NW-SE during the Middle Jurassic - Early Cretaceous rift phase in this region (Færseth et al., 1997).

Davies et al. (2001) took this view to the extreme, as they suggested that each of several sets of faults in the North Sea rift system are dip-slip normal faults that formed sequentially due to repeated variations in the extension direction, and related these changes to variations in the Middle Jurassic - Early Cretaceous regional extension direction. However, activity on NE-SW-striking fault may be explained by a simple clockwise reorientation of the extension direction in the study area toward NW-SE. Evidence for such a local rotation of the middle-late Jurassic extension is found between the Oseberg and Brage Faults, where the NW-SE-striking minor faults were inactive during the Middle Jurassic - Early Cretaceous rift phase (Fig. 12D). NE-SW-striking faults also developed in the Huldra fault block and Lomre terrace, forming a narrow NE-SW-trending zone that separates the main N-S-striking faults, on both sides (Fig. 1B). Fossen et al. (2003) found the Huldra fault block to be a secondary structure in the middle to late Jurassic rift evolution, related to marginal collapse of the Horda Platform. The zone of NE-SW-trending faults extending from 
the Oseberg area to the Huldra fault block towards the Lomre and Uer terraces (Fig. 1B) marks the northwestern collapsed margin of the Horda Platform. Seismic evidence for a basement shear zone at this location (Fossen et al., 2016) lead us to speculate that this NE-SW-trending zone is controlled by a basement structural lineament between the Horda Platform and the northern part of Viking Graben, and that activation of this basement structure in the late Jurassic caused the development of the NE-SW-striking faults (also see Færseth, 1996).

In terms of the minor NW-SE-striking faults that were active in the immediate hanging wall of the Oseberg Fault during the Middle Jurassic - Early Cretaceous rift phase (SW part of Fig. 12D), Maerten et al. $(2002,2006)$ suggested that the curved geometry of the Oseberg and Brage East faults played a great role during the initiation of the NW-SE-striking minor faults. These NW-SE-striking faults are confined to the area between the Oseberg Fault and the fault to the west, and may possibly be explained as a result of the local, block-internal stress history during the general late Jurassic extension. If so, local stress perturbation by pre-existing firstorder structures complicates fault pattern developed during a subsequent rifting phase, varying the strike of new faults around pre-existing structure to be oblique to regional extension direction.

An implication of our study is that fault pattern in multiphase rifts is the result of a combination of far-field stress, basement structures and local perturbations set up by geometry of pre-existing faults. Specifically, basement structures and pre-existing faults lead to variation in the strike of new faults from orthogonal to oblique to the regional far-field stress of rifting (Morley, 2010; Tingay et al., 2010). This is consistent with that made from physical modeling of two phases of non-coaxial extension (Henza et al., 2010; 2011), where reactivation of first-phase faults (N-S-striking faults 
in Fig. 13) and development of new faults (NE-SW-striking faults in Fig. 13) occur during the second-phase extension. In addition, their models show that new faults could strike oblique to the second-phase extension direction due to local perturbations near the reactivated first-phase faults (Fig. 13), similar to the faults developing in the immediate hanging wall of the Oseberg Fault during the Middle Jurassic - Early Cretaceous rift phase (SW part of Fig. 12D) (Maerten et al., 2002). Moreover, many of the second-phase faults cut across or terminate at reactivated first-phase faults, producing intersecting fault geometries in their model that has a well-developed first-phase fault population (Fig. 13), and our results support these conclusions. Therefore, our observations illustrate that basement structures and preexisting faults play a substantial effect on fault growth during later rift phases, which is consistent with the results from other natural rifts and physical models.

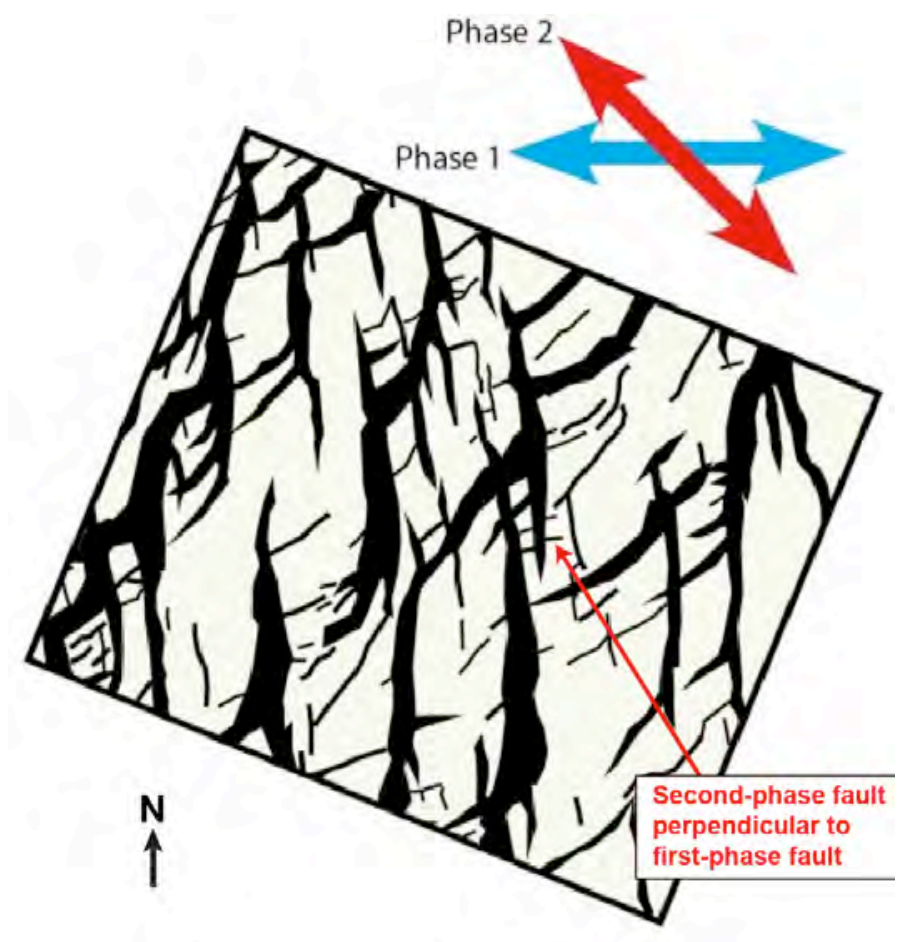

Fig. 13. Fault pattern formed by two phases of non-coaxial extension, based on Henza et al. (2011). Phase 1 extension is E-W (blue arrow), while Phase 2 extension is NW-SE (red arrow), with $45^{\circ}$ 
between the two extension directions. Black line drawings are fault heaves on the top surface of the models.

\subsection{Implications for the growth of reactivated pre-existing faults}

Several studies have found that reactivated pre-existing faults interact with secondary faults (Duffy et al., 2015; Nixon et al., 2014). Duffy et al. (2015) illustrated the interaction styles between first- and second-phase faults, such as isolated, abutting and restrained interactions, with a focus on the effect of first-phase faults on the growth of second-phase faults. Our study mainly investigates the growth history of pre-existing faults and observes that renewed growth of pre-existing faults can develop in four different ways in the Oseberg area. First, a pre-existing fault gradually propagates upward through the cover after reactivation (Fig. 14A). For example, the NNW-SSE- (BE1) and N-S-striking (BF2) segments of the Brage Fault propagate upward during the Middle Jurassic - Early Cretaceous rift phase, with a decrease in displacement upward. Second, a pre-existing fault vertically links up with a new fault in the cover, such as the northern part of the segment BF3 which shows a slight decrease in displacement from shallower and deeper levels to the middle level (Fig. 14B). Third, a pre-existing fault reactivates and propagates upward into the cover, and is then crosscut by an oppositely dipping fault, like fault F4 (Fig. 14C). Finally, the reactivated pre-existing fault terminates against an overlying and oppositely dipping fault, such as the Brage East Fault (Fig. 14D). The final case may be regarded as an example of what may be a common process, i.e. the restraining or arrest of upward propagating rift faults by an overlying and oppositely dipping fault, associated with the strain shadow of the overlying fault. In fact, the four growth models can happen at various segments of a large fault system, which will lead to irregular, non-elliptical three-dimensional fault geometries (e.g., Morley et al., 2007, 
2011). It also implies that fault interactions between faults (e.g. restraining effect in Fig. 14D) can make the reactivation and further growth of a pre-existing fault segmented in the cover, resulting in non-elliptical fault geometries.

\section{Before Rift Phase 2}

(A)

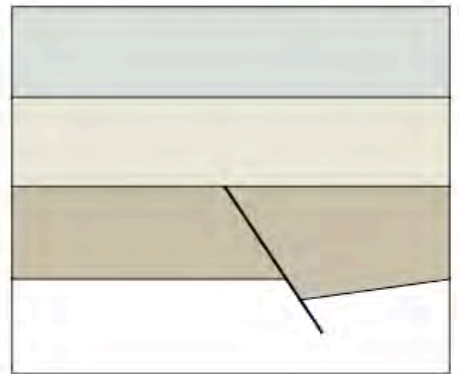

(B)

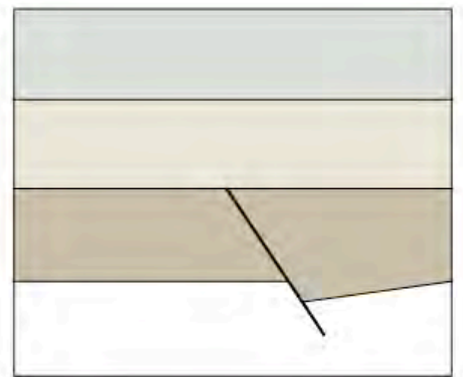

(C)

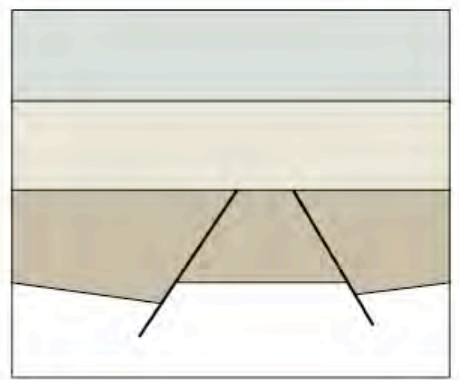

(D)

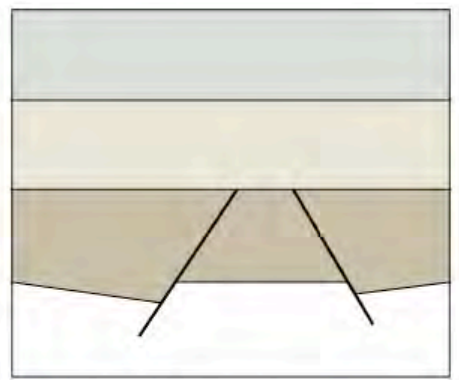

Syn-rift 1 strata
Early Rift Phase 2
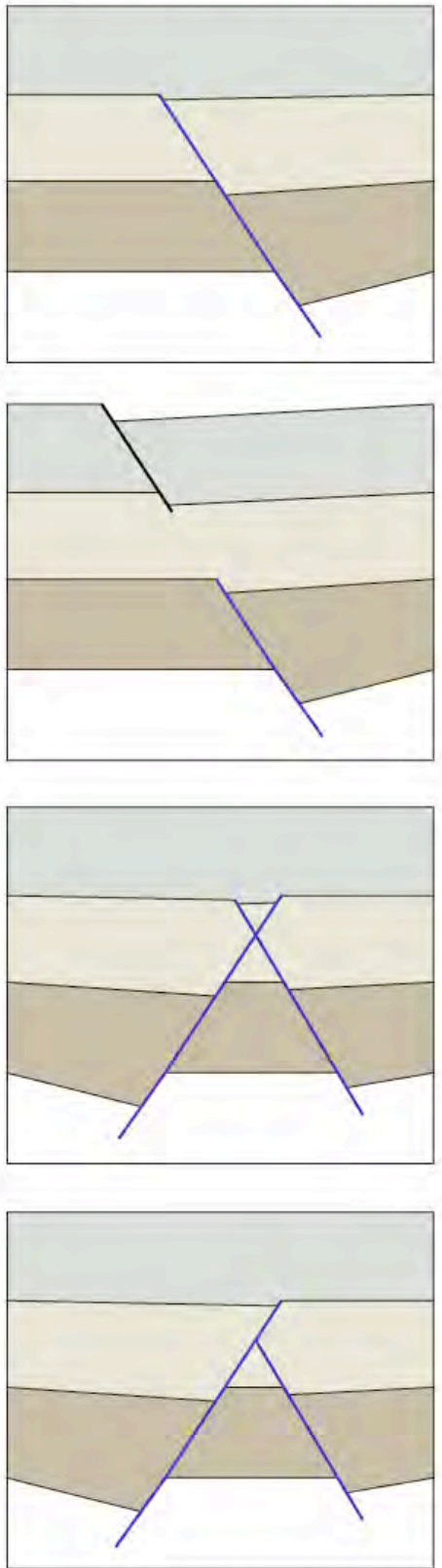

Inter-rift strata 2
Late Rift Phase 2
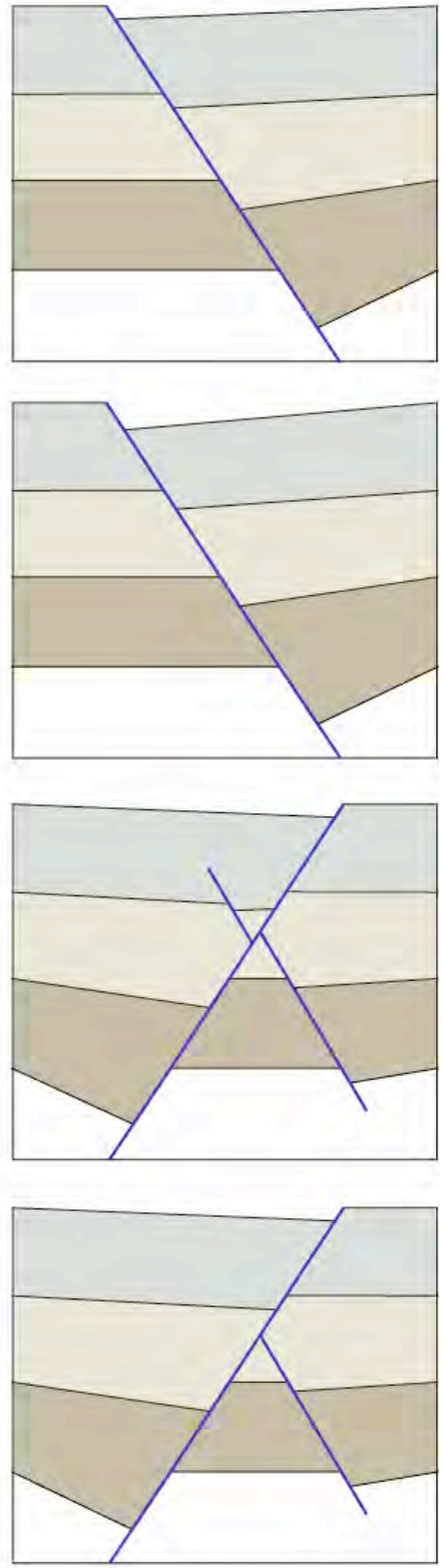

New fault

Reactivated fault

Fig. 14. Four styles of the growth of a reactivated pre-existing fault during a renewed rifting. (A) Upward propagation of a pre-existing fault in the cover during a subsequent rift phase, no influence of other faults. (B) Vertical linkage of a reactivated pre-existing fault and overlying new fault in the cover. (C) Two oppositely dipping faults propagate upward in the cover, followed by one of them crosscutting 
and offsetting the other. (D) Two oppositely dipping faults propagate upward in the cover, but one of them terminates against the plane or in the footwall block of the other one.

\section{Conclusions}

1. The evolution of fault array in the Oseberg area can be divided into four stages: (1) the Permian - Early Triassic syn-rift period characterized by N-Sand NW-SE-striking, mainly E-dipping faults; (2) early stages of inter-rift evolution, controlled by thermal subsidence and differential compaction; (3) a late inter-rift stage featuring reactivation of Triassic faults and formation of NW-SE-striking faults; (4) the Middle Jurassic - Early Cretaceous syn-rift period resulting in the development of N-S-, NW-SE- and NE-SW-striking faults that are mainly W-dipping.

2. Fault activity is significant during the late inter-rift stage, demonstrating an important Early-Middle Jurassic period of tectonic stretching during the interrift stage. Extension direction is NE-SW during the inter-rift stage, rotated clockwise as compared to E-W direction during the Permian - Early Triassic rifting, and then rotated back to E-W during the Middle Jurassic - Early Cretaceous rifting.

3. Reactivation of pre-existing faults is very significant in the Oseberg area during late inter-rift phase and Middle Jurassic - Early Cretaceous rifting, indicating that structural inheritance is common during North Sea rifting. Stress perturbation associated with reactivated pre-existing faults changes the strike of new faults to be oblique to the regional stress field, adding complexity to the fault network. 
4. Fault pattern during multiphase rifting is complicated, having faults of different strike orientations associated with reactivation of pre-existing faults and interference of basement structure. Therefore, the fault pattern developing in multiphase rifts is controlled by a combination of far-field stress, basement structures and local perturbations set up by the geometry of pre-existing faults.

5. The growth of reactivated pre-existing structure has four styles: (i) upward propagation, (ii) vertical linkage, (iii) crosscut by an oppositely dipping fault, and (iv) restrained by an oppositely dipping fault. Upward growth of a reactivated pre-existing structure may be influenced by its neighboring faults in the cover, leading to more non-elliptical fault geometries at the interaction zone.

\section{Acknowledgments}

This contribution forms part of the MultiRift Project funded by the Research Council of Norway's PETROMAKS program (Project number 215591) and Statoil to the University of Bergen and partners Imperial College, University of Manchester and University of Oslo. We thank Statoil for providing seismic and well data in this study, and permission to publish the results of this study. We also thank Rebecca E. Bell, Oliver B. Duffy, Johan S. Claringbould and Antje Lenhart for constructive suggestions regarding the displacement analysis, and Alan Roberts for critically commenting on an earlier version of the manuscript.

\section{Reference}

Andersen, T. B. \& Jamtveit, B. 1990. Uplift of deep crust during orogenic extensional collapse: a model based on field studies in the Sogn-Sunnfjord region of western Norway. Tectonics 9, 1097-1112. 
Anderson, E.M., 1951. The Dynamics of Faulting and Dyke Formation with Applications to Britain. Oliver \& Boyd, Edinburgh.

Badley, M., Price, J., Dahl, C.R., Agdestein, T., 1988. The structural evolution of the northern Viking Graben and its bearing upon extensional modes of basin formation. Journal of the Geological Society $145,455-472$.

Badley, M.E., Egeberg, T., Nipen, O., 1984. Development of rift basins illustrated by the structural evolution of the Oseberg feature, Block 30/6, offshore Norway. Journal of the Geological Society 141, 639-649.

Bartholomew, I., Peters, J., Powell, C., 1993. Regional structural evolution of the North Sea: oblique slip and the reactivation of basement lineaments. In: Petroleum Geology Conference Series, 4. Geological Society, London, pp. 1109-1122. Geological Society of London.

Baudon, C., Cartwright, J., 2008a. Early stage evolution of growth faults: 3D seismic insights from the Levant Basin, Eastern Mediterranean. Journal of Structural Geology 30, 888898

Baudon, C., Cartwright, J., 2008b. The kinematics of reactivation of normal faults using high resolution throw mapping. Journal of Structural Geology 30, 1072-1084.

Baudon, C., Cartwright, J.A., 2008c. 3D seismic characterisation of an array of blind normal faults in the Levant Basin, Eastern Mediterranean. Journal of Structural Geology 30, 746-760.

Bell, R.E., Jackson, C.A.L., Whipp, P.S., Clements, B., 2014. Strain migration during multiphase extension: Observations from the northern North Sea. Tectonics 33, 19361963

Cartwright, J. A., Trudgill, B. D., \& Mansfield, C. S. (1995). Fault growth by segment linkage: an explanation for scatter in maximum displacement and trace length data from the Canyonlands Grabens of SE Utah. Journal of Structural Geology, 17(9), 1319-1326. 
Cartwright, J., Bouroullec, R., James, D. \& Johnson, H. 1998. Polycyclic motion history of some Gulf Coast growth faults from high-resolution displacement analysis. Geology, $26,819-822$.

Coward, M., Dewey, J., Hempton, M., Holroyd, J., 2003. Tectonic Evolution. The Millennium Atlas: Petroleum Geology of the Central and Northern North Sea, pp. 17-33.

Cowie, P.A., Underhill, J.R., Behn, M.D., Lin, J., Gill, C.E., 2005. Spatio-temporal evolution of strain accumulation derived from multi-scale observations of Late Jurassic rifting in the northern North Sea: A critical test of models for lithospheric extension. Earth and Planetary Science Letters 234, 401-419.

Davies, R., Turner, J., Underhill, J., 2001. Sequential dip-slip fault movement during rifting: a new model for the evolution of the Jurassic trilete North Sea rift system. Petroleum Geoscience 7, 371-388.

Dawers, N. H., \& Anders, M. H. (1995). Displacement-length scaling and fault linkage. Journal of Structural Geology, 17(5), 607-614.

Doré, A., Gage, M., 1987. Crustal alignments and sedimentary domains in the evolution of the North Sea, North-east Atlantic Margin and Barents Shelf, Petroleum geology of north west Europe. Graham and Trotman London, pp. 1131-1148.

Dreyer, T., Whitaker, M., Dexter, J., Flesche, H., Larsen, E., 2005. From spit system to tidedominated delta: integrated reservoir model of the Upper Jurassic Sognefjord Formation on the Troll West Field, Geological Society, London, Petroleum Geology Conference series. Geological Society of London, pp. 423-448.

Duffy, O.B., Bell, R.E., Jackson, C.A., Gawthorpe, R.L., Whipp, P.S., 2015. Fault growth and interactions in a multiphase rift fault network: Horda Platform, Norwegian North Sea. Journal of Structural Geology 80, 99-119.

Dutton, D. M., \& Trudgill, B. D., 2009. Four-dimensional analysis of the sembo relay system, offshore angola: implications for fault growth in salt-detached settings. Aapg Bulletin, 93(6), 763-794. 
Færseth, R., 1996. Interaction of Permo-Triassic and Jurassic extensional fault-blocks during the development of the northern North Sea. Journal of the Geological Society 153, $931-944$.

Færseth, R.B., Knudsen, B.E., Liljedahl, T., Midbøe, P.S., Søderstrøm, B., 1997. Oblique rifting and sequential faulting in the Jurassic development of the northern North Sea. Journal of Structural Geology 19, 1285-1302.

Færseth, R.B., Ravnas, R., 1998. Evolution of the Oseberg Fault-Block in context of the northern North Sea structural framework. Mar Petrol Geol 15, 467-490.

Fossen, H. (1992). The role of extensional tectonics in the Caledonides of south Norway. Journal of structural geology, 14(8), 1033-1046.

Fossen, H., 1998. Advances tn understanding the post-Caledonian structural evolution of the Bergen area, West Norway.

Fossen, H., Hesthammer, J., Johansen, T. E. S., \& Sygnabere, T. O. (2003). Structural geology of the Huldra field, northern North Sea-A major tilted fault block at the eastern edge of the Horda platform. Marine and Petroleum Geology, 20(10), 11051118.

Fossen, H., 2010. Extensional tectonics in the North Atlantic Caledonides: a regional view. Geological Society, London, Special Publications 335, 767-793.

Fossen, H., \& Rotevatn, A. (2016). Fault linkage and relay structures in extensional settings-A review. Earth-Science Reviews, 154, 14-28.

Frankowicz, E., McClay, K., 2010. Extensional fault segmentation and linkages, Bonaparte Basin, outer North west shelf, Australia. AAPG bulletin 94, 977-1010.

Giba, M., Walsh, J., Nicol, A., 2012. Segmentation and growth of an obliquely reactivated normal fault. Journal of Structural Geology 39, 253-267.

Glennie, K.W., 1987. Outline of North Sea history and structural framework. In: Introduction to the Petroleum Geology of the North Sea, third ed. Blackwell Scientific Publications, Oxford, pp. 34-77. 
Gupta, A., \& Scholz, C. H. (2000). A model of normal fault interaction based on observations and theory. Journal of Structural Geology, 22(7), 865-879.

Healy, D., Blenkinsop, T. G., Timms, N. E., Meredith, P. G., Mitchell, T. M. \& Cooke, M. L. 2015. Polymodal faulting: Time for a new angle on shear failure. Journal of Structural Geology 80, 57-71.

Helland-Hansen, W., Ashton, M., Lømo, L., Steel, R., 1992. Advance and retreat of the Brent delta: recent contributions to the depositional model. Geological Society, London, Special Publications 61, 109-127.

Henza, A.A., Withjack, M.O., Schlische, R.W., 2010. Normal-fault development during two phases of non-coaxial extension: An experimental study. Journal of Structural Geology 32, $1656-1667$.

Henza, A.A., Withjack, M.O., Schlische, R.W., 2011. How do the properties of a pre-existing normal-fault population influence fault development during a subsequent phase of extension? Journal of Structural Geology 33, 1312-1324.

Hongxing, G., Anderson, J.K., 2007. Fault throw profile and kinematics of Normal fault: conceptual models and geologic examples. Geol. J. China Univ 13, e88.

Jackson, C.A.-L., Rotevatn, A., 2013. 3D seismic analysis of the structure and evolution of a salt-influenced normal fault zone: a test of competing fault growth models. Journal of Structural Geology 54, 215-234.

Korme, T., Acocella, V., Abebe, B., 2004. The role of pre-existing structures in the origin, propagation and architecture of faults in the Main Ethiopian Rift. Gondwana Research 7, 467-479.

Kyrkjebø, R., Gabrielsen, R., Faleide, J., 2004. Unconformities related to the JurassicCretaceous synrift-post-rift transition of the northern North Sea. Journal of the Geological Society 161, 1-17.

Lepercq, J.-Y., Gaulier, J.-M., 1996. Two-stage rifting in the North Viking Graben area (North Sea): inferences from a new three-dimensional subsidence analysis. Mar. Petroleum Geol. 13, 129-148. 
Lepvrier, C., Fournier, M., Bérard, T., Roger, J., 2002. Cenozoic extension in coastal Dhofar (southern Oman): implications on the oblique rifting of the Gulf of Aden. Tectonophysics 357, 279-293.

Lervik, K., 2006. Triassic lithostratigraphy of the northern North Sea Basin. Norsk Geologisk Tidsskrift 86, 93.

Long, J., Imber, J., 2010. Geometrically coherent continuous deformation in the volume surrounding a seismically imaged normal fault-array. Journal of Structural Geology 32, 222-234.

Maerten, L., Gillespie, P., \& Pollard, D. D. (2002). Effects of local stress perturbation on secondary fault development. Journal of Structural Geology, 24(1), 145-153.

Maerten, L., Gillespie, P. \& Daniel, J.-M. 2006. Three-dimensional geomechanical modeling for constraint of subseismic fault simulation. American Association of Petroleum Geologists Bulletin 90, 1337-1358.

Morley, C.K., 1999. Patterns of displacement along large normal faults: Implications for basin evolution and fault propagation, based on examples from East Africa. American Association of Petroleum Geology Bulletin 83, 613-634.

Morley, C. K., 2010. Stress re-orientation along zones of weak fabrics in rifts: an explanation for pure extension in 'oblique' rift segments?. Earth \& Planetary Science Letters, 297(3), 667-673.

Morley, C. K., P. Charusiri, \& I. Watkinson,, 2011, Structural geology of Thailand during the Cenozoic. In: Ridd, M.F., Barber, A.J., \& M. J. Crow (eds) The Geology of Thailand, Memoirs of the Geological Society, London, 273-334.

Morley, C. K., S. Gabdi, and K. Seusutthiya, 2007, Fault superimposition and linkage resulting from stress changes during rifting: Examples from $3 D$ seismic data, Phitsanulok Basin, Thailand: Journal of Structural Geology, v. 29, p. 646-663.

Nixon, C. W., Sanderson, D. J., Dee, S. J., Bull, J. M., Humphreys, R. J., \& Swanson, M. H. (2014). Fault interactions and reactivation within a normal-fault network at Milne Point, Alaska. AAPG Bulletin, 98(10), 2081-2107. 
Nottvedt, A., Gabrielsen, R. H., \& Steel, R. J., 1995. Tectonostratigraphy and sedimentary architecture of rift basins, with reference to the northern North Sea. Marine and Petroleum Geology, 12(8), 881-901.

Odinsen, T., Christiansson, P., Gabrielsen, R.H., Faleide, J.I., Berge, A.M., 2000a. The geometries and deep structure of the northern North Sea rift system. Geological Society, London, Special Publications 167, 41-57.

Odinsen, T., Reemst, P., Beek, P.V.D., Faleide, J.I., Gabrielsen, R.H., 2000b. PermoTriassic and Jurassic extension in the northern North Sea: results from tectonostratigraphic forward modelling. Geological Society, London, Special Publications 167, 83-103.

Paton, D.A., Underhill, J.R., 2004. Role of crustal anisotropy in modifying the structural and sedimentological evolution of extensional basins: the Gamtoos Basin, South Africa. Basin Research 16, 339-359.

Peacock, D., Sanderson, D., 1991. Displacements, segment linkage and relay ramps in normal fault zones. Journal of Structural Geology 13, 721-733.

Ravnås, R., Nøttvedt, A., Steel, R.J., Windelstad, J., 2000. Syn-rift sedimentary architectures in the Northern North Sea. Geological Society, London, Special Publications 167, 133177.

Roberts, A., Yielding, G., Badley, M., 1990. A kinematic model for the orthogonal opening of the Late Jurassic North Sea rift system, Denmark-Mid Norway. Tectonic Evolution of the North Sea Rifts, Clarendon Press, Oxford, 180-199.

Roberts, A., Yielding, G., Kusznir, N., Walker, I., Dorn-Lopez, D., 1993. Mesozoic extension in the North Sea: constraints from flexural backstripping, forward modelling and fault populations, Geological Society, London, Petroleum Geology Conference series. Geological Society of London, pp. 1123-1136.

Roberts, A., Yielding, G., Kusznir, N., Walker, I., Dorn-Lopez, D., 1995. Quantitative analysis of Triassic extension in the northern Viking Graben. Journal of the Geological Society $152,15-26$. 
Smethurst, M., 2000. Landeoffshore tectonic links in western Norway and the northern North Sea. J. Geol. Soc. 157, 769-781.

Steel, R., 1993. Triassic-Jurassic megasequence stratigraphy in the Northern North Sea: rift to post-rift evolution, Geological Society, London, Petroleum Geology Conference series. Geological Society of London, pp. 299-315.

Steel, R., Ryseth, A., 1990. The Triassic-Early Jurassic succession in the northern North Sea: megasequence stratigraphy and intra-Triassic tectonics. Geological Society, London, Special Publications 55, 139-168.

Stewart, I.J., Rattey, R.P., Vann, I.R., 1992. Structural style and the habit of hydrocarbons in the North Sea. In: Larsen, R.M., Brekke, H., Larsen, B.T., Talleraas, E. (Eds.), Structural and Tectonic Modelling and its Application to Petroleum Geology, 1. NPF Spec. Publ, pp. 197-220.

Ter Voorde, M., Faerseth, R.B., Gabrielsen, R.H., Cloetingh, S.A.P.L., 2000. Repeated lithosphere extension in the northern Viking Graben: a coupled or a decoupled rheology? Geological Society, London, Special Publications 167, 59-81.

Tingay, M. R. P., Morley, C. K., Hillis, R. R., \& Meyer, J., 2010. Present-day stress orientation in thailand's basins. Journal of Structural Geology, 32(2), 235-248.

Tomasso, M., Underhill, J.R., Hodgkinson, R.A., Young, M.J., 2008. Structural styles and depositional architecture in the Triassic of the Ninian and Alwyn North fields: Implications for basin development and prospectivity in the Northern North Sea. Mar Petrol Geol 25, 588-605.

Underhill, J.R., Partington, M.A., 1993. Jurassic thermal doming and deflation in the North Sea: implications of the sequence stratigraphic evidence. Geol. Soc. Lond. 4, 337-345. Vetti, V. V., \& Fossen, H. (2012). Origin of contrasting Devonian supradetachment basin types in the Scandinavian Caledonides. Geology, 40(6), 571-574.

Walsh, J., Nicol, A., Childs, C., 2002. An alternative model for the growth of faults. Journal of Structural Geology 24, 1669-1675. 
Walsh, J.J., Watterson, J., 1991. Geometric and kinematic coherence and scale effects in normal fault systems. In: Geological Society, London, Special Publications, vol. 56, pp. 193-203.

Whipp, P., Jackson, C., Gawthorpe, R., Dreyer, T., Quinn, D., 2014. Normal fault array evolution above a reactivated rift fabric; a subsurface example from the northern Horda Platform, Norwegian North Sea. Basin Research 26, 523-549.

Yielding, G., Badley, M.E., Roberts, A.M., 1992. The structural evolution of the Brent Province. Geological Society, London, Special Publications 61, 27-43.

Young, M.J., Gawthorpe, R.L., Hardy, S., 2001. Growth and linkage of a segmented normal fault zone; the Late Jurassic Murchison-Statfjord North Fault, northern North Sea. Journal of Structural Geology 23, 1933-1952.

Ziegler, P., 1992. North Sea rift system. Tectonophysics 208, 55-75.

Ziegler, P.A., 1990. Tectonic and Palaeogeographic Development of the North Sea Rift System. Tectonic Evolution of the North Sea Rifts. Clarendon Press, Oxford, pp. 1-36. 